\title{
DETECTION OF WASTE DUMPING LOCATIONS IN LANDFILL USING MULTI-TEMPORAL LANDSAT THERMAL IMAGES
}

\author{
by \\ Jasravia Gill
}

B. Tech, Civil Engineering, B.B.S.B Engineering College, India, 2015

\begin{abstract}
A Major Research Project
presented to Ryerson University
\end{abstract}

in partial fulfillment of the

requirements for the degree of

Master of Engineering

in the program of

Civil Engineering

Toronto, Ontario, Canada, 2018

(C) Jasravia Gill, 2018 


\section{AUTHOR'S DECLARATION}

I hereby declare that I am the sole author of this MRP. This is a true copy of the MRP, including any required final revisions.

I authorize Ryerson University to lend this MRP to other institutions or individuals for the purpose of scholarly research.

I further authorize Ryerson University to reproduce this MRP by photocopying or by other means, in total or in part, at the request of other institutions or individuals for the purpose of scholarly research.

I understand that my MRP may be made electronically available to the public.

Jasravia Gill

(Department of Engineering and Architectural Science) 


\section{Abstract}

The practice of solid waste disposal in conventional landfills has always been associated with adverse environmental impacts, leading to the migration of landfill gas and bad odour to the proximate areas. Apart from the obnoxious fumes and hazardous leachate, the potential of heat generation within these vast disposal sites has been observed during the aerobic and anaerobic decomposition process. Therefore, this study aims to demonstrate how to utilize thermal remote sensing technique to monitor the heat flux, which can aid in detecting the waste dumping location with a case study in the Jeleeb Al-Shuyoukh landfill in Kuwait, where the record of its physical boundary was found missing. Landsat TM/ETM+ images for ten-year (1985 to 1994) were acquired and subsequently processed with atmospheric correction so as to compute the land surface temperature (LST). Through overlay analysis, the multi-temporal LST contours were combined in order to detect the most probable dumping locations within the landfill. With reference to the 50 borehole locations drilled by the Environmental Public Authority of Kuwait, our results derived during the summer season yielded a better accuracy (72\%) comparing to that derived during the winter season (70\%). This can be explained by the waste decomposition process reaches to the peak in summer and more heat flux can be captured from the ground cover. In addition, the dumping locations buried with construction waste were found to have higher LST as compared to the sites containing organic waste in most of the cases, except for certain locations which contained the mixture of construction and organic waste in winter season.

Keywords: Landfill, Land Surface Temperature, Thermal Remote Sensing, Waste Dumping 


\section{Acknowledgements}

First and foremost, enormous gratitude to my supervisor Dr. Ahmed Shaker for giving me this opportunity to work on this project. Also, my sincere thanks to Dr. Mohamed Al-Ahmad from the Environment Public Authority (EPA) of Kuwait who provided the background information and the borehole data for accuracy assessment.

Further, I would like to express my deepest gratitude to Dr. Wai Yeung Yan for his unwavering support and mentorship throughout the entire project. Besides providing sufficient time for enhancement of my research skills, Dr. Yan has been a constant source of motivation and enthusiasm. I am also thankful to Dr. Kamil Faisal for his help and guidance.

I deeply acknowledge my sincere thanks and regards to my family members who always believed in me and gave me all possible mental support and resources to fulfil my dream of continuing my education.

Above all, I would thank Almighty GOD, for all his blessings. 


\section{Table of Contents}

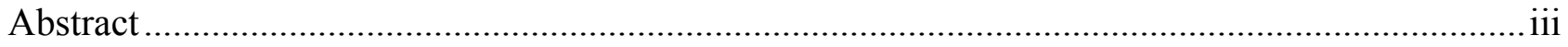

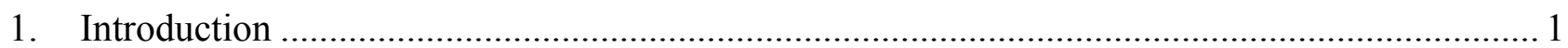

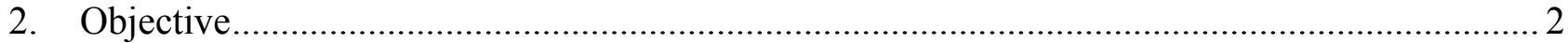

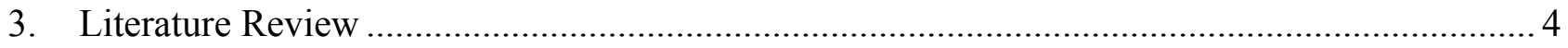

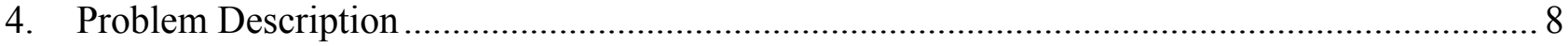

4.1 Study Area

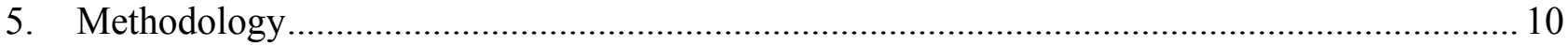

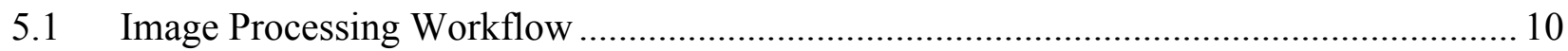

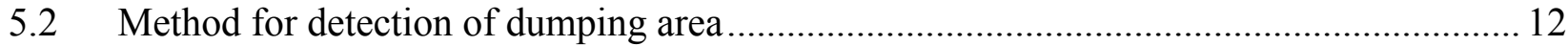

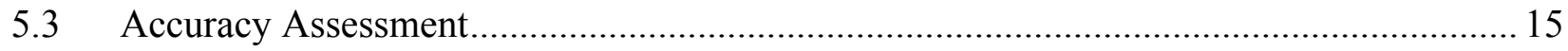

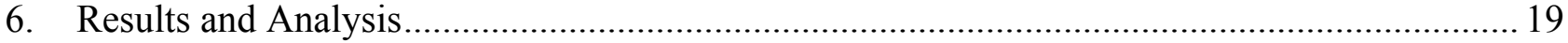

6.1 Comparison between the results derived during the winter season and summer season ......... 19

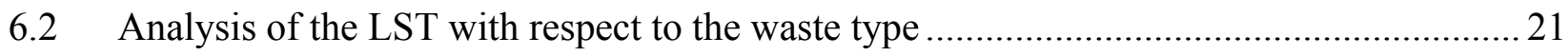

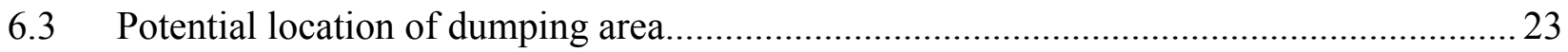

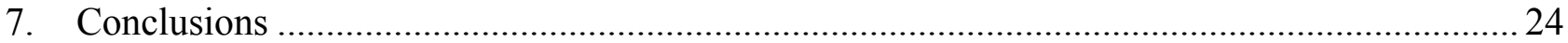

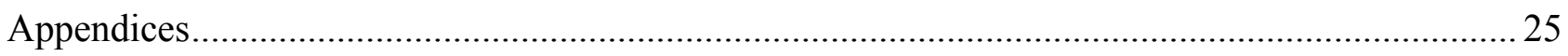

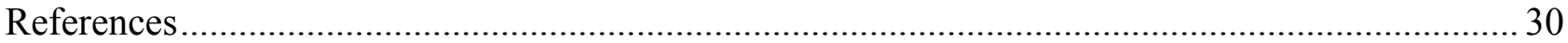




\section{List of Figures}

Figure 1: Study area: Jeleeb Al-Shuyoukh landfill and the location of the 50 boreholes. ................. 10

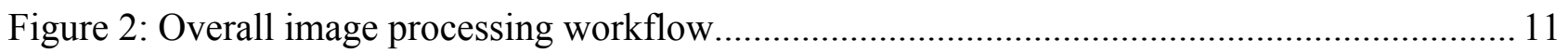

Figure 3: Showing Raster to Vector conversion of study site images.............................................. 13

Figure 4: Overall accuracy of dumping area detection with respect to different breaking intervals. 19

Figure 5- Analysis of LST with respect to waste type. (Construction and Demolition Debris (CDD), Organic Waste (OW), and a mixture of Construction and Demolition Debris and Organic waste (CDD-OW).

Figure 6- Probability map showing the possible dumping location within the Al-Jeleeb Shuyoukh landfill. 
Detection of waste dumping locations in Landfill using Multi-Temporal Landsat Thermal Images, Jasravia Gill, M. Eng, Ryerson University, 2018.

\section{List of Tables}

Table 1: Showing the Borehole Number, Location, Type of Waste and Depth........................... 18

Table 2: Showing the acquisition dates of the downloaded Landsat Images used in the project...... 29 


\section{Introduction}

Despite being the least recommended waste management solution in the waste management hierarchy, landfilling is still the most predominant waste management alternative in many countries. Leachate and gas generation in landfills is an unavoidable consequence of waste decomposition process. The infiltration of these bi-products into the local environment could pose serious threats to degraded quality of environment as well as human health (Fadel et al,1995), (Slonecker et al.,2010). Therefore, the rigorous monitoring and detection of vast areas of waste disposal sites is a persistent challenge and cost-intensive endeavour for concerned authorities. Consequently, the application of remote sensing has emerged as a cost-effective and feasible solution for monitoring, detecting and analysing the spatial and temporal extents and changes of waste dumping sites and landfills (Hanson et al., 2010).

Therefore, this project intends to extend the application of remote sensing in monitoring of such a vast landfill of Jeleeb Al-Shuyoukh located in the City of Kuwait. Records prove that this is one of the largest landfill sites in the country covering a total area of $5.5 \mathrm{Km}^{2}$ and received about 2500 tons of waste every day (Schrapp and Mutairi, 2010), (Saleh M. Al-Muzaini, 2009). But due to the Gulf War during 1990's, the records of physical boundary of the landfill site were lost and there is lack of knowledge about the exact boundary and the potential waste dumping site locations, within the landfill site.

Due to the vast area of the landfill, it is very expensive and time consuming endeavour to exactly know the location of waste dumping and landfill gas emission sites through ground measurements 
Detection of waste dumping locations in Landfill using Multi-Temporal Landsat Thermal Images, Jasravia Gill, M. Eng, Ryerson University, 2018.

such as collecting boreholes data. Therefore, remote sensing could be used as a cost effective and time extensive method to study the locations within the landfill site with higher Land Surface Temperature and hence landfill gas emission. Although being covered by a thick layer of covering layer of natural soil in 2002 , but there is considerable evidence from the literature reviewed that the landfill site still continues to have high land surface temperature as compared to the air temperature (Yan at el., 2014.) According to existing literature, not only the land surface temperature values, but the concentration of volatile organic compounds has also shown considerable variations in different parts of landfill (AlAhmad et al., 2012). Hence, the adopted method of using Land Surface Temperature from the multi-temporal Landsat images, could emerge as a successful technology for knowing the exact location of waste dumping sites within any landfill having a vast area, where conventional methods of landfill monitoring would not be helpful.

\section{Objective}

Despite of many successful attempts of landfill monitoring, most of the existing studies have focused on using remote sensing techniques to monitor well-recorded and existing landfill sites. A lack of studies has been found, which use such technique and the underneath phenomenon to detect and look for the suspicious dumping activities or the exact location of unauthorized/unrecorded landfill area.

Therefore, in this study, we attempt to conduct a "reverse engineering" approach by using the LST derived by multi-temporal satellite thermal images to detect the dumping area of an unrecorded landfill site in the Jeleeb Al-Shuyoukh landfill of Kuwait, where it has a lack of recorded boundary after the Gulf war occurred in early 1990s. In addition, such landfill site has been raised with several environmental issues, where there is a prolonged discussion regarding the expansion of the 
Detection of waste dumping locations in Landfill using Multi-Temporal Landsat Thermal Images, Jasravia Gill, M. Eng, Ryerson University, 2018.

airport as well as the surrounding commercial/industrial activities on top of the land suited on this landfill. As such, the Environment Public Authority (EPA) of Kuwait is looking for a viable solution to detect the boundary of the Jeleeb Al-Shuyoukh landfill

The primary objective of this project is to extract the areas with high values of Land Surface Temperature by using the thermal bands of Landsat images. In other words, the main motive of extracting the LST values from the Landsat images is to successfully determine the most probable locations of waste dumping sites within the landfill area. Those areas which emitted highest amount of heat flux were classified as the potential waste dumping locations. This was done by doing the analysing the areas with LST above mean, above one standard deviation and above two standard deviations for about a period of ten years.

Apart from this, the comparison of the extracted LST in summer and the winter seasons in Kuwait has been done in order to check the comparative accuracy of the extracted results in the respective seasons. Three major categories of waste analysed were: Construction and Demolition Waste (CDD), Organic Waste (OW) and mixture of CDD and Organic Waste. These three categories were derived based on information on the borehole data provided by the EPA of Kuwait.

Furthermore, it is to be noted that the type of waste dumped in the landfill site varied very widely. Therefore, another interest of the study would be to investigate the relationship between the variations of the LST depending on the type of the waste type with the help of the borehole data of the landfill site.

Finally, producing a topographic map which could clearly highlight the boundary and the probable locations of waste dumping sites within the Jeleeb Al-Shuyoukh landfill of Kuwait, would be the final objective of this project. 


\section{Literature Review}

Leachate and gas generation in landfills are an unavoidable consequence of waste decomposition process. After a comprehensive research, Yeşiller et al. $(2005,2008)$ claimed that waste decomposition is always associated with the generation of heat and is accompanied by the production of Landfill Gas (LFG) and leachate in waste mass, as a result of the continuous aerobic and anaerobic waste decomposition processes. The major reason for long term heat generation from landfill sites according to Nastev et al. (2001), is the production of Landfill Gas which primarily consist of methane and carbon dioxide. According to El-Faitli et al. (2015), the thermal properties of landfill and heat generating potential of a municipal solid waste dumping site is a result of the biological, chemical and physical waste decomposition processes prevailing within the waste. ElFadel et al. (1995) and Slonecker et al. (2010) studied the effects of infiltration of these bi-products into the local environment and concluded that these could pose serious threats to degraded quality of environment as well as human health. However, the study by McKendry (2002) claimed that these harmful effects of landfill leachate infiltration could be minimized by converting the LFG into renewable energy.

As the age of refuse, disposed in the landfill site increases, there is a shift of the decomposition phase from aerobic to anaerobic resulting in the formation of more methane as concluded by a study by El-Fadel et al. (1997). Also, according to the same study, when considering the age of refuse and the gas formation, the latter phase of waste decomposition is more prominent for the analysis of long term heat emission from waste. The decomposition activity and hence the heat emission from landfill sites could also vary depending upon the ambient seasonal and climatic changes as well as 
Detection of waste dumping locations in Landfill using Multi-Temporal Landsat Thermal Images, Jasravia Gill, M. Eng, Ryerson University, 2018.

the type of refuse in the waste disposal site. Long term high temperatures were observed in a study conducted by Rees (1980) under anaerobic conditions. Also, the study highlighted the high potential of domestic or organic waste to reach high temperatures even while anaerobic conditions.

A study by Lefebvre et al. (2000) investigated the role of aerobic phase in increasing the temperature of landfill by measuring the instantaneous waste's temperature during the waste placement. The study claimed that there exist significant temperature variations in the initial phase of waste decomposition due to the aerobic activities. Field observations also proved that temperatures as high as $45^{\circ} \mathrm{C}$ or above (in case reaching to the anaerobic condition) could originate in landfills in areas of temperate climates as described in a study by J.F Rees, (1980). Although the landfill gas production rate decreases exponentially with time but still the emission of heat from the landfill sites results in slight elevation in the temperature of the waste disposal sites as compared to the surrounding areas concluded the study by Kwarteng \& Al-Enezi (2004). Similar findings were reported by another study by Vaverková and Adamcová (2014).

Another comprehensive study by Yeşiller et al. (2003) concluded that thermal heat change pattern in the waste disposal sites are governed by multiple factors, including the operating conditions of the landfill site and its climatic and seasonal variations. Significant difference of temperature was observed with respect to the spatial variation of waste. For instance, the central location containing dense proportion of waste witnessed higher temperature as compared to those near the vicinity of the landfill boundary area. The former study also proved that shallow depths of waste disposal sites are sensitive to variations in the seasonal temperatures. The edge regions and locations of shallow depths (upto $8 \mathrm{~m}$ ) followed the similar pattern of temperature variation as the air temperature of the surroundings. Whereas, seasonal temperature variations at central locations of waste disposal were considerably steady. Also, consistent increment in the temperature was witnessed with the depth 
Detection of waste dumping locations in Landfill using Multi-Temporal Landsat Thermal Images, Jasravia Gill, M. Eng, Ryerson University, 2018.

below ground surface. With increase in air temperature, the temperature difference of the waste mass under the ground surface and the surface layers was expected to decrease.

Furthermore, precipitation was deemed to elevate the heat gain in the waste. The apparent reason for this is due to the optimal condition of decomposition activity. Similar findings were reported by Yoshida et al. (2003) in their long-term examination of Tokyo Port landfill for a period of 30 years, concluded that the high base temperatures of landfills are a function of both aerobic and anaerobic decomposition of waste and that the estimated base temperature was over $30^{\circ} \mathrm{C}$ over the same period of time. The study also highlighted that the in-filtered water through the landfill liner layer affects the temperature of the landfill significantly.

A peak landfill temperature of $30^{\circ} \mathrm{C}$ was affirmed by Koerner et al. (2006), while temperature monitoring of dry landfills. The maximum heat generation was witnessed approximately after 6 years of the waste placement which decreased eventually. Another study by R.K Rowe (1998) investigated the performance of long term landfill barrier systems and confirmed the same results that the temperature at the bottom of a waste disposal site is dependent upon the nature or type of waste, landfilling rate and the thickness of layers of waste.

Thus, the heat generation capacity of waste disposal sites has been considerably evidenced from the existing literature. This inherent characteristics of thermal heat emission from waste dumping sites facilitates the use of other techniques in detection and monitoring of these areas. Among which satellite remote sensing techniques have been recently utilized to detect and map the land surface temperatures (LST) of waste dumping sites by using multi-temporal Landsat data, particularly for large area. Kwarteng et al. (2004) analysed the LST and the presence of any heated minerals in the 
Detection of waste dumping locations in Landfill using Multi-Temporal Landsat Thermal Images, Jasravia Gill, M. Eng, Ryerson University, 2018.

Al-Qurain landfill of Kuwait by using the satellite image data (IKONOS, Landsat MSS and Landsat

TM) for a period of 28 years from 1972 to 2000. Yan et al. (2014) also adopted multi-temporal Landsat images (from 1984 to 2010) to monitor two adjacent municipal solid waste disposal sites in city of Ottawa, Ontario, Canada. Mahmood et al. (2016) studied the bio-thermal effects of waste dumping, around a landfill facility by analysing the health of vegetation through various vegetative indices and as well as the LST derived by Landsat images.

Another study by Jones et al. (1994) indicated the possibility of landfill gas migration by mapping the response of vegetation health to landfill gas. Khalid et al. (2016) studied the bio-thermal effects of waste dumping, around a landfill facility by analysing the health of vegetation through various vegetative indices and the land surface temperature. Infra-red cameras were used in a study conducted by Lewis et al. (2003) to investigate the potential of this technology for detecting the leakage of gases from a landfill site. The study concluded that the success of use of such technology is a function of varying weather and operating conditions. A recent study by Manzo et al. (2015) focussed on photogrammetry, in-situ thermal analysis and chemical surveys to develop the change detection techniques for environmental monitoring of waste dumping sites.

All these studies have proven that the landfill sites usually have a higher LST with respect to its immediate surroundings by a few to ten degrees Celsius, depending on the seasons, weather conditions and the operating stage of the landfill sites as indicated by a study of landfill monitoring by Yan et al. (2014). Despite of these successful attempts, most of the existing studies focused on using remote sensing techniques to monitor well-recorded and existing landfill sites. A lack of studies is found using such technique and the underneath phenomenon to detect and look for the suspicious dumping activities or the exact location of unauthorized/unrecorded landfill area. 
Detection of waste dumping locations in Landfill using Multi-Temporal Landsat Thermal Images, Jasravia Gill, M. Eng, Ryerson University, 2018.

Therefore, in this study, we attempt to conduct a "reverse engineering" approach by using the LST derived by multi-temporal satellite thermal images to detect the dumping area of an unrecorded landfill site in the Jeleeb Al-Shuyoukh landfill of Kuwait, where it has a lack of the recorded boundary after the Gulf war occurred in early 1990s.

\section{Problem Description}

One of the adverse environmental effects of this landfill site on the general public is the inconvenience caused due to release of unpleasant odour from the landfill, since 1992. Apart from the discharge of bad odour from the landfill site boundaries, the leakage of leachate from the landfill is another plight (Schrapp and Mutairi, 2010). Previous studies conducted for testing the composition and Landfill Gas Emissions (LFG) and concentration of total Volatile Organic Compounds (VOC) have shown considerable variations in the VOC concentration in different parts of the same landfill site. Apparently, this difference in the recorded values was due to the variation in waste composition at different parts of the landfill. Five major constituents of the VOC or the LFG emission were toluene, ethylbenzene, benzene, Meta, para and ortho-styrene and xylene. (AlAhmad et al., 2012).

Existing studies also highlighted more problems of Jeleeb Al-Shuyoukh landfill including contamination of groundwater as well as the emission of methane from landfill, which are mainly caused by the lack of safe treatment and further unauthorized dumping. Moreover, the danger may be transmitted to serious diseases through birds that may transmit diseases to humans in the city (Alraimedia, 2012).

More problems exist through the disposal of a large quantity of liquid waste including sewage, water, sewage and other liquids, especially in the south part of the landfill site, which amounts up to 
Detection of waste dumping locations in Landfill using Multi-Temporal Landsat Thermal Images, Jasravia Gill, M. Eng, Ryerson University, 2018.

9 million gallons per week according to the latest statistics at the Municipality of Kuwait (Beatona, 2013). Therefore, the local public has urged the authority to perform cleaning and rehabilitation for the surface of the landfill site. Nevertheless, the exact dumping location of the landfill is unknown with all possible records being lost during the Gulf war in 1990s. As a result, it provokes this research by exploiting the inherent characteristics of thermal heat emission from the landfill through analysing the Landsat-derived LST in order to locate possible dumping area.

\subsection{Study Area}

Jeleeb Al-Shuyoukh landfill of Kuwait, located in the southern part of the City of Kuwait is one of the largest landfill sites in Kuwait covering a total area of $5.5 \mathrm{~km}^{2}$ and received about 2,500 tons of waste daily (Schrapp and Mutairi, 2010), see Fig. 1. The landfill site is contiguous to the residential area of Abdulla Al-Mubarak on south-eastern side and in close proximity with International Airport of Kuwait on the other side (see Fig. 1). This landfill was designed for disposing off municipal solid waste from 1970 to 1992 but continued to receive waste until 2000 (Al-Muzaini, 2009). The type of waste being received comprised of mixture of industrial, commercial and domestic waste. Much of the construction and demolition waste was confined in the South-Eastern part of the landfill (Schrapp and Mutairi, 2010). The estimated quantity of construction and demolition waste buried inside the landfill during its operational period is approximately 3 million $\mathrm{m}^{3}$ (AlAhmad et al., 2012). 
Detection of waste dumping locations in Landfill using Multi-Temporal Landsat Thermal Images, Jasravia Gill, M. Eng, Ryerson University, 2018.

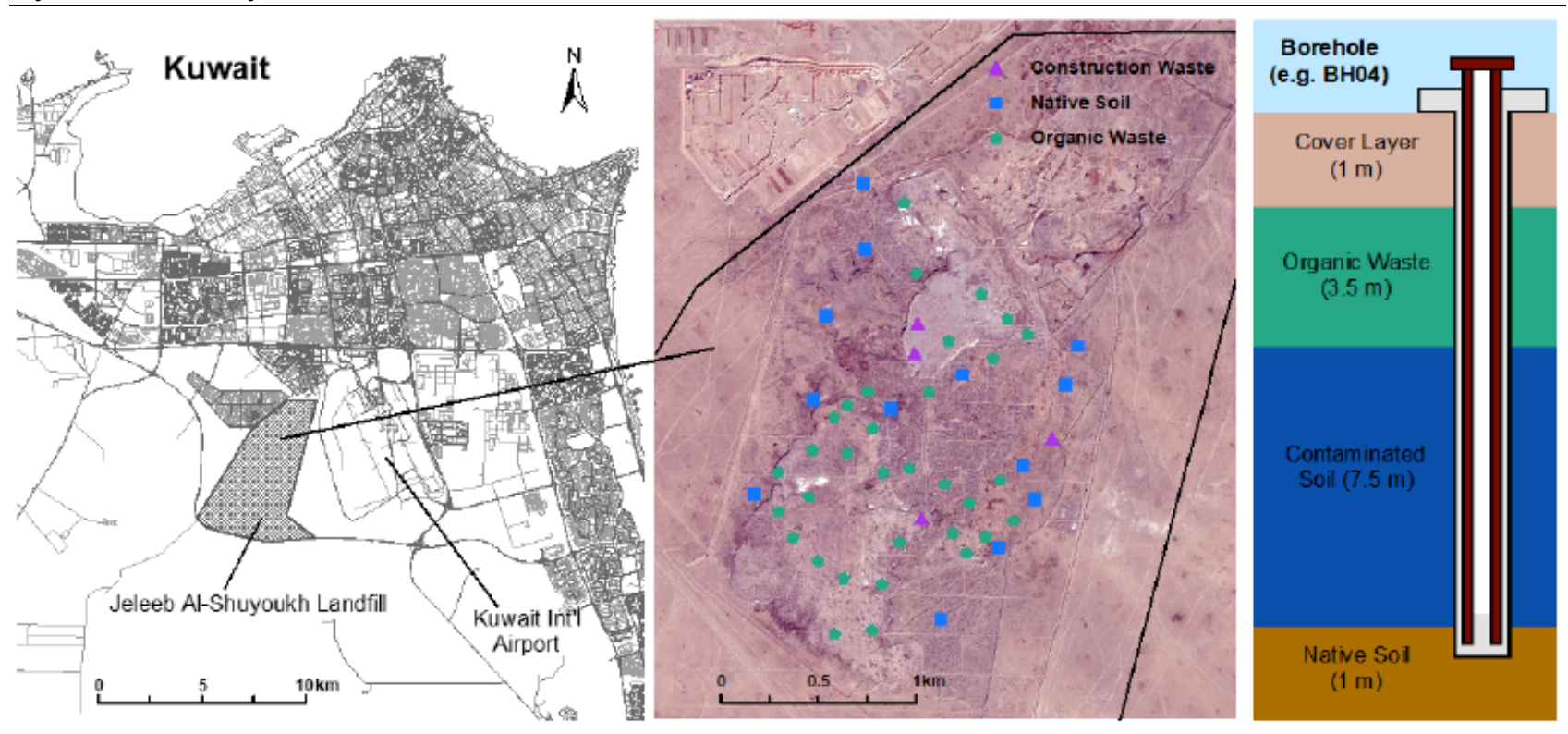

Figure 1: Study area: Jeleeb Al-Shuyoukh landfill and the location of the 50 boreholes.

Other parts of the landfill contained the mixture of all other types of waste, most of which is municipal solid waste and count for approximately 20 million $\mathrm{m}^{3}$. The total depth of waste varies from 4-23 $\mathrm{m}$ in different parts of the landfill. In 2002, the landfill was capped with a layer if 1-m thick soil after the waste being burnt. The EPA of Kuwait started drilling boreholes in the landfill site in order to measure the landfill gas emission, where the measurements of the landfill gas emission from these 50 boreholes (up to $29 \mathrm{~m}$ deep) started to be recorded in 2008. (AlAhmad et al., 2012).

\section{Methodology}

\subsection{Image Processing Workflow}

Fig. 2 shows the overall image processing workflow to compute the LST using Landsat thermal imagery in order to serve the subsequent detection of the suspicious location of waste dumping. The task was accomplished in four major phases: data collection, image processing, LST computation and accuracy assessment using the 50 boreholes provided by the EPA of Kuwait. 


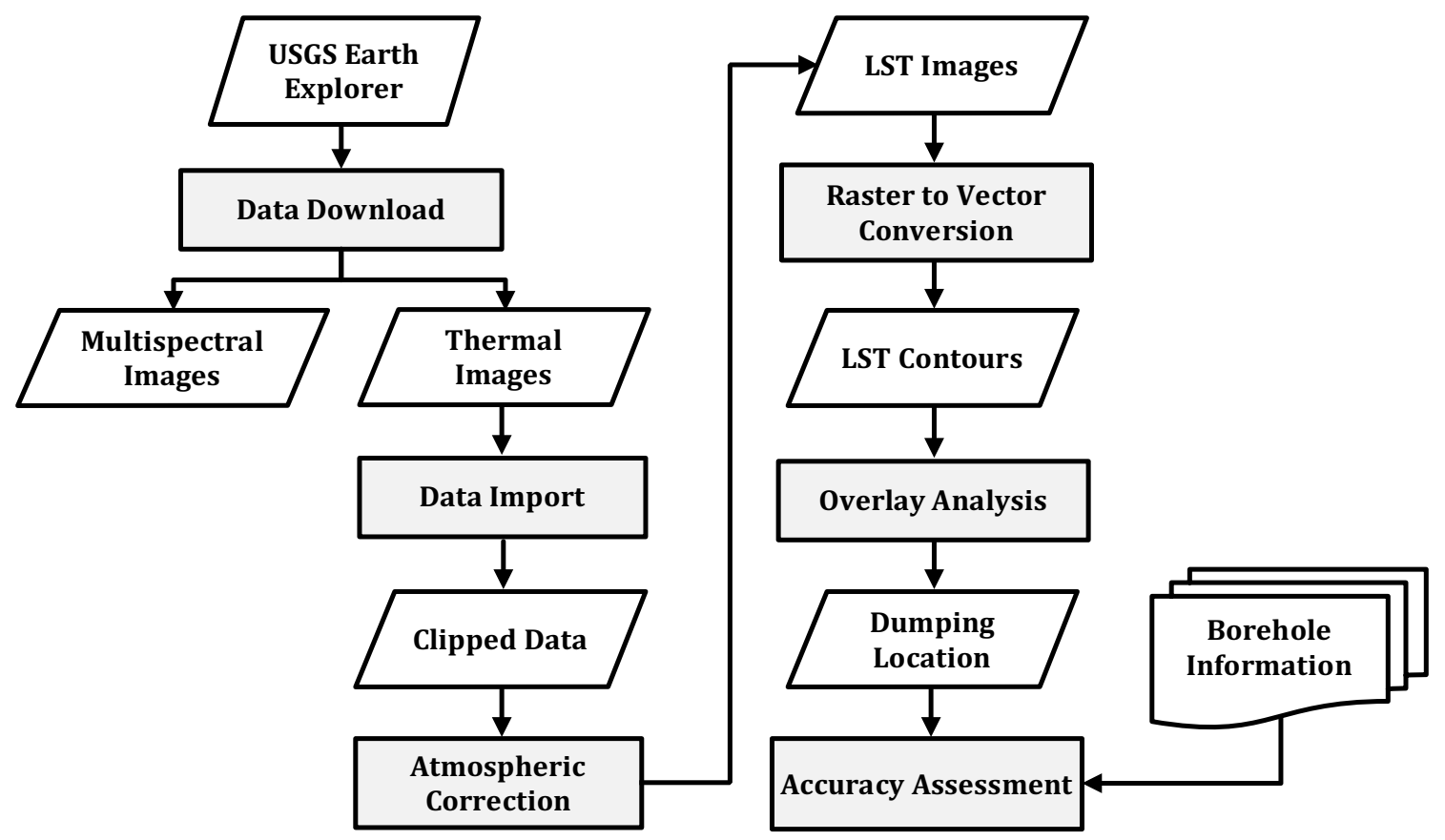

Figure 2: Overall image processing workflow.

In the first phase, the multi-temporal Landsat $\mathrm{TM}$ and $\mathrm{ETM}^{+}$images of the study area, located in Al-Jaleeb, Al-Farwanyah, Kuwait $\left(29^{0} 18^{\prime} 42^{\prime \prime} \mathrm{N}, 47^{0} 284^{\prime} 54^{\prime}\right.$ E) were acquired from USGS Earth Explorer and used as the main dataset for this study. The remote sensing data, in form of Landsat images covering a temporal range of ten years from 1985 to 1994, were downloaded. These datasets included both summer and winter seasons in Kuwait so as to determine the LST of the landfill site in two different seasons. A total of ten images were downloaded for the summer season corresponding to the hottest months in Kuwait (July to August) from the year 1985-1994. Furthermore, nine more images were downloaded for the winter season (January to March) for the same span of nine years from 1985-1993 as there were no images available for the year 1994 for the winter season. Consequently, only nine years of dataset were used to compute the LST Contours for winter season. 
Detection of waste dumping locations in Landfill using Multi-Temporal Landsat Thermal Images, Jasravia Gill, M. Eng, Ryerson University, 2018.

The second phase involved the transfer of all downloaded images to PCI Geomatica Version 2017.

The need for geo-referencing was eliminated since all the downloaded images were in L1T format. Clipping and sub-setting of the images were done for the sake of working on the same stretch of the area for all the images. Prior to the computation of LST, atmospheric correction was conducted using ATCOR2 model (Richter and Schläpfer, 2005) for which the sensor and image settings, the acquisition date, month and year and also the solar zenith and solar azimuth were obtained from the image metadata. For the visibility and ground reflectance conditions, the aerosol type and the condition of the study site were chosen as desert and mid-latitude summer or mid-latitude winter respectively. Finally, the LST is computed by first converting the pixel value $\left(Q_{c a l}\right)$ into relative spectral reflectance into $L_{\lambda}$ is top-of-atmosphere (TOA) spectral radiance [in unit $\left.\mathrm{W} /\left(\mathrm{m}^{2} \cdot \operatorname{srad} \cdot \mu \mathrm{m}\right)\right]$ :

$$
L_{\lambda}=M_{L} Q_{c a l}+A_{L}
$$

where $M_{L}$ and $A_{L}$ are the band-specific multiplicative rescaling factor from the metadata and bandspecific additive rescaling, respectively, in which both can be found in the Landsat metadata file. The LST can be computed using the following equation:

$$
T=\frac{K_{2}}{\ln \left(\frac{K_{1}}{L_{\lambda}}+1\right)}
$$

where $T$ is the at-satellite brightness temperature $(K), K_{1}\left[\right.$ in unit $\left.\mathrm{W} /\left(\mathrm{m}^{2} \cdot \operatorname{srad} \cdot \mu \mathrm{m}\right)\right]$ is the bandspecific thermal conversion constant from the metadata, and $K_{2}$ [in unit $K$ ] is the band -specific thermal conversion constant from the metadata.

\subsection{Method for detection of dumping area}

For the computation of the LST and detecting the specific waste dumping sites within the study area, only the thermal band of the image was used as an input. The multispectral images were only used in creating the probability maps of waste dumping areas in the final section of this report. The 
Detection of waste dumping locations in Landfill using Multi-Temporal Landsat Thermal Images, Jasravia Gill, M. Eng, Ryerson University, 2018.

extracted LST results were exported in GeoTIFF format for further analysis in ArcGIS ArcMap V10.5.

Subsequently, all the LST images were converted into contour lines and polygons based on the pixel value (i.e. LST). Such a raster to vector conversion was carried out in order to specifically cover the area of the landfill site and hence discarding the remaining part of the image (example of raster to vector conversion shown in figure 3). Since the bio-decomposition process causes heat generation of the waste (Yeşiller et al., 2005 and 2008), therefore the dumping location can be predicted by assuming it having a relatively higher LST. Thus, those areas found within the landfill site, of which had an above mean temperature as well the temperature values greater than mean plus one standard deviation (1S.D.) and mean plus two standard deviations (2 S.D.), were extracted for each image. The same process was followed for all the available datasets in order to acquire all those areas within the landfill site that contained higher than the abovementioned LST values.
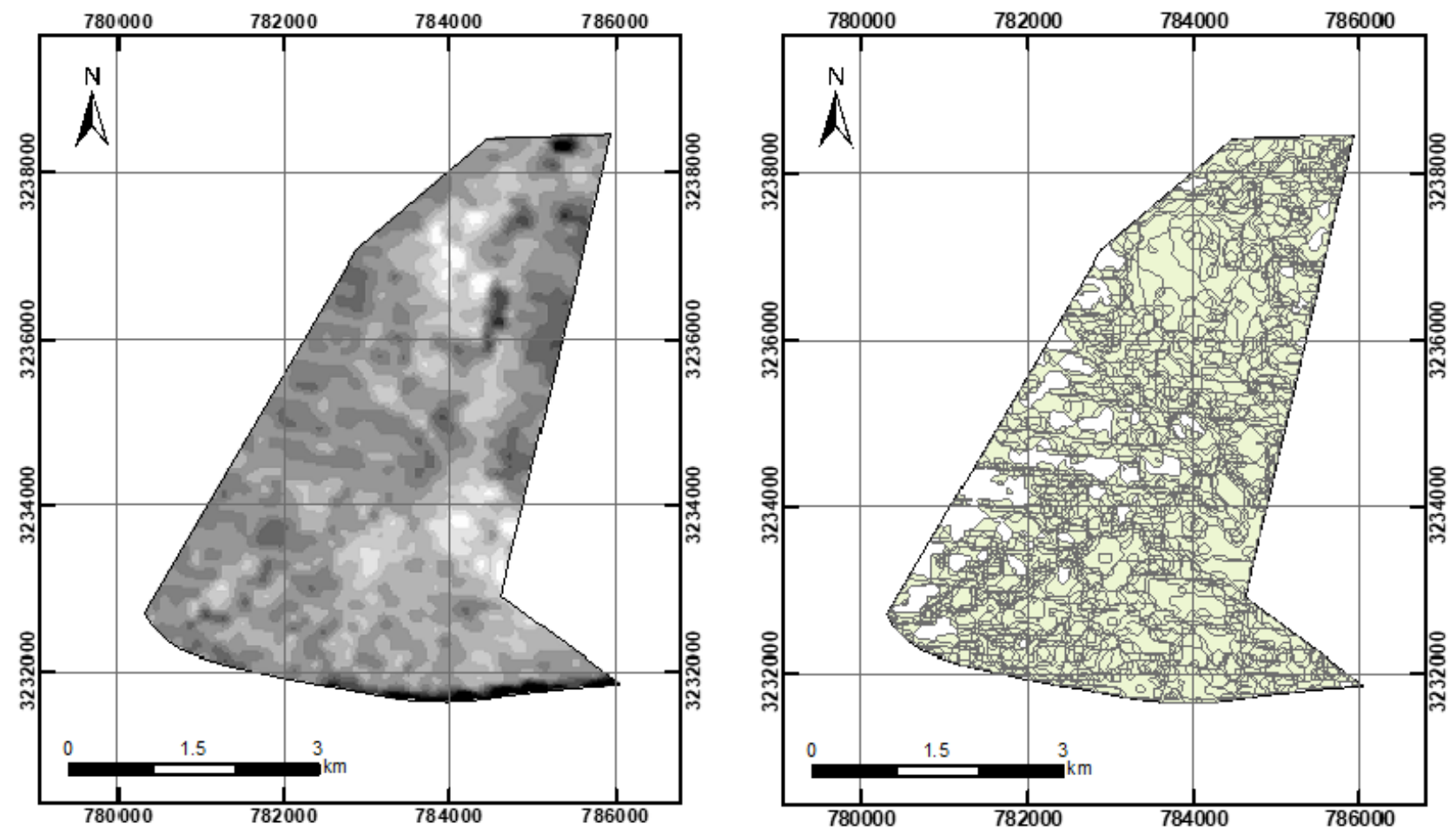

Figure 3: Showing Raster to Vector conversion of study site images. 
Detection of waste dumping locations in Landfill using Multi-Temporal Landsat Thermal Images, Jasravia Gill, M. Eng, Ryerson University, 2018.

The clustering of polygons was followed by merging the above mean LST polygon sets for the first ten years in order to form a single polygon set representing those suspicious locations within the landfill site, which accounted for above mean LST values for a period of ten years. Narrowing down the temperature range, another two polygon sets were obtained for LST values above 1 S.D. and above 2 S.D. by merging the polygon sets of ten years in both the cases. As a result, three polygon sets were obtained corresponding to LST of the landfill site above mean, above 1 S.D. and above 2 S.D. respectively for each season. In order to completely enclose the final polygons, union was performed on the resulting polygons so as to eliminate the possibility of any errors. At the same time, this tool could also generate multipart features in the output which were rectified using a Count Overlapping Polygons algorithm. Also, the joint count of the overlapping polygons was calculated using this program. This helped in obtaining the sites with maximum joint counts of the LST polygons and hence statistically analysing the most probable locations of the waste dumping sites. The highest number of these joint counts (overlap of the polygons) corresponded to the most probable location of waste dumping sites associated with the highest LST.

Breaking Interval: Based on the LST values of the landfill area, the whole landfill area was classified into following two categories: 1) landfill 2) non-landfill. In order to accurately recover the dumping location within the landfill, different breaking intervals were examined, where the breaking interval is basically the number of the overlapping temperature polygons. Each year corresponded to one LST polygon. As the study was conducted for ten years data from 1985-1994, the maximum number of overlapping polygons could be 10 . The areas with the maximum number of overlapping regions were classified as the most probable locations of dumping sites. For instance, when a breaking interval of 2, (i.e. 1-2, 2-10) was used, which implies that those locations 
Detection of waste dumping locations in Landfill using Multi-Temporal Landsat Thermal Images, Jasravia Gill, M. Eng, Ryerson University, 2018.

within the landfill site with the LST polygons of 1-2 years being intersected were classified as landfill and rest of the areas were classified as non-landfill. Similarly, the breaking interval of 9 (i.e. $1-9,9-10)$ reflected that the areas in which the LST contours from nine years intersected were classified as landfill and the others as non-landfill. The areas classified as landfill in such case depicted strong affirmation of the presence of waste dumping locations as the highest number of LST contours overlapped in this condition.

\subsection{Accuracy Assessment}

The accuracy assessment of the task was executed by overlaying the classification results with the ground truth point data in the form of the 50 borehole's readings, provided by the EPA of Kuwait (see Table. 1). However, the accuracy of detected dumping location could only be assessed for the Northern part of the landfill, since there is a lack of borehole information for the South-Eastern part of the landfill. The depth of the boreholes and the type of waste in each borehole were recorded and the presence of the waste dumping locations were accessed by matching the consistency of the derived results and the ground truth points. Finally, the three major types of waste dumped in the landfill, i.e. construction waste $(\mathrm{CW})$ and organic waste (OW) and a mixture of both (CDD-OW) were further analyzed with the respective LST. Table 1 shows the detailed description of the type of waste in each borehole. Also, the location and the depth of the particular type of waste found in each borehole is depicted below. The location of these boreholes in the study site according to the type of waste is shown in Figure 1. 
Detection of waste dumping locations in Landfill using Multi-Temporal Landsat Thermal Images, Jasravia Gill, M. Eng, Ryerson University, 2018.

\begin{tabular}{|c|c|c|c|c|}
\hline & Locatio & Boreholes & \multirow[t]{2}{*}{ Type of Waste } & \multirow[t]{2}{*}{$\begin{array}{l}\text { Depth of } \\
\text { the waste } \\
\text { category } \\
\text { (m) }\end{array}$} \\
\hline Borehole & Longitude & Latitude & & \\
\hline BH1 & 493184.070000000010000 & 234556.950000000010000 & NS & $0-13.5$ \\
\hline $\mathrm{BH} 2$ & 493125.960000000020000 & 234360.780000000000000 & NS & $0-9.0$ \\
\hline $\mathrm{BH} 3$ & 493054.590000000030000 & 234085.500000000000000 & $\begin{array}{l}\mathrm{NS} \\
\mathrm{CDD}\end{array}$ & $\begin{array}{l}0-3 \\
3-12\end{array}$ \\
\hline BH4 & 492968.299999999990000 & 233773.410000000000000 & NS & $0-13.5$ \\
\hline BH5 & 492910.109999999990000 & 233942.700000000010000 & NS & $0-9.0$ \\
\hline BH6 & 492791.080000000020000 & 233872.530000000000000 & $\begin{array}{l}\text { Cover Layer } \\
\text { OW } \\
\text { CS }\end{array}$ & $\begin{array}{l}0-1.0 \\
1-4.5 \\
4.5-12 \\
\end{array}$ \\
\hline BH7 & 492630.960000000020000 & 233754.760000000010000 & $\begin{array}{l}\text { Cover Layer } \\
\text { OW } \\
\text { CS } \\
\text { NS } \\
\end{array}$ & $\begin{array}{l}0-1.0 \\
1-8 \\
8-13 \\
13-13.15\end{array}$ \\
\hline $\mathrm{BH} 8$ & 492715.349999999980000 & 233583.450000000010000 & $\begin{array}{l}\text { Cover Layer } \\
\text { OW } \\
\text { NS }\end{array}$ & $\begin{array}{l}0-1.0 \\
1-13 \\
13-13.5 \\
\end{array}$ \\
\hline BH9 & 492857.710000000020000 & 233663.929999999990000 & $\begin{array}{l}\text { Cover Layer } \\
\text { OW }\end{array}$ & $\begin{array}{l}0-0.5 \\
0.5-7.5\end{array}$ \\
\hline BH10 & 492780.900000000020000 & 233520.609999999990000 & NS & $0-11.5$ \\
\hline BH11 & 492488.020000000020000 & 233155.600000000010000 & NS & $0-8.5$ \\
\hline BH12 & 492133.000000000000000 & 233102.820000000010000 & $\begin{array}{l}\text { Cover Layer } \\
\text { OW } \\
\text { CS }\end{array}$ & $\begin{array}{l}0-1.5 \\
1.5-9 \\
9-11\end{array}$ \\
\hline BH13 & 491943.280000000030000 & 233084.200000000010000 & $\begin{array}{l}\text { Cover Layer } \\
\text { OW } \\
\text { CS }\end{array}$ & $\begin{array}{l}0-1.0 \\
1-1.5 \\
1.5-11\end{array}$ \\
\hline BH14 & 492181.739999999990000 & 233337.340000000000000 & $\begin{array}{l}\text { Cover Layer } \\
\text { OW } \\
\text { CS and NS }\end{array}$ & $\begin{array}{l}0-1.0 \\
1-7 \\
7-12 \\
\end{array}$ \\
\hline BH15 & 491989.060000000000000 & 233372.079999999990000 & $\begin{array}{l}\text { Cover Layer } \\
\text { OW } \\
\text { CS }\end{array}$ & $\begin{array}{l}0-1.0 \\
1-10 \\
10-12 \\
\end{array}$ \\
\hline BH16 & 492274.859999999990000 & 233552.850000000010000 & $\begin{array}{l}\text { Cover Layer } \\
\text { OW } \\
\text { CS }\end{array}$ & $\begin{array}{l}0-1.5 \\
1.5-12 \\
12-15\end{array}$ \\
\hline BH17 & 492385.020000000020000 & 233676.540000000010000 & $\begin{array}{l}\text { Cover Layer } \\
\text { CDD } \\
\text { OW } \\
\text { CS } \\
\end{array}$ & $\begin{array}{l}0-3.0 \\
3-4.5 \\
4.5-25 \\
25-28 \\
\end{array}$ \\
\hline BH18 & 492548.140000000010000 & 233604.929999999990000 & $\begin{array}{l}\text { Cover Layer } \\
\text { OW } \\
\text { CS }\end{array}$ & $\begin{array}{l}0-1.0 \\
1-7 \\
7-12 \\
\end{array}$ \\
\hline BH19 & 492618.270000000020000 & 233497.989999999990000 & $\begin{array}{l}\text { Cover Layer } \\
\text { OW } \\
\text { CS }\end{array}$ & $\begin{array}{l}0-1.5 \\
1.5-7.5 \\
7.5-9\end{array}$ \\
\hline $\mathrm{BH} 20$ & 492508.590000000030000 & 233849.100000000010000 & $\begin{array}{l}\text { Cover Layer } \\
\text { OW }\end{array}$ & $\begin{array}{l}0-1.0 \\
1-7\end{array}$ \\
\hline
\end{tabular}


Detection of waste dumping locations in Landfill using Multi-Temporal Landsat Thermal Images, Jasravia Gill, M. Eng, Ryerson University, 2018.

\begin{tabular}{|c|c|c|c|c|}
\hline & & & $\mathrm{CS}$ & $7-12$ \\
\hline $\mathrm{BH} 21$ & 492751.599999999980000 & 234497.310000000000000 & $\begin{array}{l}\text { Cover Layer } \\
\text { OW } \\
\text { CS } \\
\text { CDD } \\
\end{array}$ & $\begin{array}{l}0-1.0 \\
1-10 \\
10-11 \\
11-11.5\end{array}$ \\
\hline $\mathrm{BH} 22$ & 492928.570000000010000 & 234619.390000000010000 & $\begin{array}{l}\text { Cover Layer } \\
\text { OW } \\
\text { CS } \\
\text { NS } \\
\end{array}$ & $\begin{array}{l}0-3.0 \\
3-10.5 \\
10.5-14 \\
14-15 \\
\end{array}$ \\
\hline $\mathrm{BH} 23$ & 492828.650000000020000 & 234699.329999999990000 & $\begin{array}{l}\text { Cover Layer } \\
\text { OW } \\
\text { CDD }\end{array}$ & $\begin{array}{l}0-1.5 \\
1.5-4 \\
4-12 \\
\end{array}$ \\
\hline $\mathrm{BH} 24$ & 492692.140000000010000 & 234827.140000000010000 & $\begin{array}{l}\text { Cover Layer } \\
\text { OW } \\
\text { CS }\end{array}$ & $\begin{array}{l}0-1.5 \\
1.5-12 \\
12-14 \\
\end{array}$ \\
\hline BH25 & 492524.729999999980000 & 234586.870000000000000 & $\begin{array}{l}\text { Cover Layer } \\
\text { OW } \\
\text { CDD } \\
\text { OW } \\
\end{array}$ & $\begin{array}{l}0-2.0 \\
2-6 \\
6-10.5 \\
10.5-16 \\
\end{array}$ \\
\hline $\mathrm{BH} 26$ & 492596.500000000000000 & 234411.899999999990000 & $\mathrm{NS}$ & 12.5 \\
\hline $\mathrm{BH} 27$ & 492424.299999999990000 & 234322.399999999990000 & OW & $0-1.0$ \\
\hline $\mathrm{BH} 28$ & 492298.700000000010000 & 235292.140000000010000 & $\begin{array}{l}\text { Cover Layer } \\
\text { OW } \\
\text { CS }\end{array}$ & $\begin{array}{l}0-1.0 \\
1-7.5 \\
7.5-9 \\
\end{array}$ \\
\hline BH29 & 492091.049999999990000 & 235391.500000000000000 & NS & 11.5 \\
\hline $\mathrm{BH} 30$ & 492366.799999999990000 & 234674.049999999990000 & $\begin{array}{l}\text { Cover Layer } \\
\text { CDD }\end{array}$ & $\begin{array}{l}0-1.0 \\
1-15\end{array}$ \\
\hline BH31 & 492361.400000000020000 & 234932.920000000010000 & $\begin{array}{l}\text { Cover Layer } \\
\text { OW } \\
\text { CS }\end{array}$ & $\begin{array}{l}0-1.0 \\
1-12 \\
12-15 \\
\end{array}$ \\
\hline BH32 & 492095.599999999980000 & 235048.810000000000000 & NS & 10.5 \\
\hline BH33 & 491896.070000000010000 & 234715.609999999990000 & NS & 10.5 \\
\hline BH34 & 492351.030000000030000 & 234524.959999999990000 & $\begin{array}{l}\text { Cover Layer } \\
\text { CDD }\end{array}$ & $\begin{array}{l}0-3.0 \\
3-12 \\
\end{array}$ \\
\hline BH35 & 491837.609999999990000 & 234284.149999999990000 & NS & 8.0 \\
\hline BH36 & 491527.390000000010000 & 233797.429999999990000 & NS & 6.0 \\
\hline BH37 & 492110.789999999980000 & 234326.359999999990000 & $\begin{array}{l}\text { Cover Layer } \\
\text { OW } \\
\text { CS }\end{array}$ & $\begin{array}{l}0-1.0 \\
1-4.5 \\
4.5-7.5 \\
\end{array}$ \\
\hline BH38 & 492231.950000000010000 & 234237.329999999990000 & NS & 12.0 \\
\hline BH39 & 492138.130000000000000 & 234136.380000000000000 & $\begin{array}{l}\text { Cover layer } \\
\text { OW }\end{array}$ & $\begin{array}{l}0-1.0 \\
1-16 \\
\end{array}$ \\
\hline BH40 & 492323.979999999980000 & 233932.280000000000000 & $\begin{array}{l}\text { Cover Layer } \\
\text { OW } \\
\text { CS } \\
\text { NS } \\
\end{array}$ & $\begin{array}{l}0-1.0 \\
1-9 \\
9-10.5 \\
10.5-12 \\
\end{array}$ \\
\hline BH41 & 492190.520000000020000 & 233911.859999999990000 & $\begin{array}{l}\text { Cover Layer } \\
\text { OW }\end{array}$ & $\begin{array}{l}0-2.0 \\
2-18\end{array}$ \\
\hline BH42 & 492006.280000000030000 & 234010.149999999990000 & $\begin{array}{l}\text { Cover Layer } \\
\text { OW } \\
\text { CS } \\
\text { OW } \\
\end{array}$ & $\begin{array}{l}0-1.0 \\
1-9 \\
9-13.5 \\
13.5-15 \\
\end{array}$ \\
\hline BH43 & 492006.950000000010000 & 234254.890000000010000 & $\begin{array}{l}\text { Cover Layer } \\
\text { OW } \\
\text { CS }\end{array}$ & $\begin{array}{l}0-1.5 \\
1.5-9 \\
9-12\end{array}$ \\
\hline
\end{tabular}


Detection of waste dumping locations in Landfill using Multi-Temporal Landsat Thermal Images, Jasravia Gill, M. Eng, Ryerson University, 2018.

\begin{tabular}{|c|c|c|c|c|}
\hline & & & NS & $12-13.5$ \\
\hline $\mathrm{BH} 44$ & 491938.270000000020000 & 234193.799999999990000 & $\begin{array}{l}\text { Cover Layer } \\
\text { OW } \\
\text { CS }\end{array}$ & $\begin{array}{l}0-1.5 \\
1.5-9 \\
9-15\end{array}$ \\
\hline $\mathrm{BH} 45$ & 491829.310000000000000 & 234025.179999999990000 & $\begin{array}{l}\text { Cover Layer } \\
\text { OW } \\
\text { CS } \\
\text { NS }\end{array}$ & $\begin{array}{l}0-1.0 \\
1-7.5 \\
7.5-12 \\
12-13.5\end{array}$ \\
\hline $\mathrm{BH} 46$ & 491809.950000000010000 & 233783.510000000010000 & $\begin{array}{l}\text { Cover Layer } \\
\text { OW } \\
\text { CS }\end{array}$ & $\begin{array}{l}0-1.0 \\
1-12 \\
12-13.5\end{array}$ \\
\hline BH47 & 491674.477000000010000 & 233914.370000000000000 & $\begin{array}{l}\text { Cover Layer } \\
\text { OW } \\
\text { CS }\end{array}$ & $\begin{array}{l}0-1.0 \\
1-7 \\
7-10 \\
10-12 \\
\end{array}$ \\
\hline $\mathrm{BH} 48$ & 491652.960000000020000 & 233712.980000000010000 & $\begin{array}{l}\text { Cover Layer } \\
\text { OW } \\
\text { CS }\end{array}$ & $\begin{array}{l}0-0.5 \\
0.5-7.5 \\
7.5-9\end{array}$ \\
\hline $\mathrm{BH} 49$ & 491728.359999999990000 & 233576.649999999990000 & $\begin{array}{l}\text { Cover Layer } \\
\text { OW } \\
\text { CS } \\
\end{array}$ & $\begin{array}{l}0-1.0 \\
1-6 \\
6-8 \\
\end{array}$ \\
\hline BH50 & 491856.659999999970000 & 233457.690000000000000 & $\begin{array}{l}\text { Cover Layer } \\
\text { OW } \\
\text { CS } \\
\text { NS }\end{array}$ & $\begin{array}{l}0-0.5 \\
0.5-7.5 \\
7.5-10 \\
10-12\end{array}$ \\
\hline
\end{tabular}

Table 1: Showing the Borehole Number, Location, Type of Waste and Depth. 


\section{Results and Analysis}

\subsection{Comparison between the results derived during the winter season and summer season}

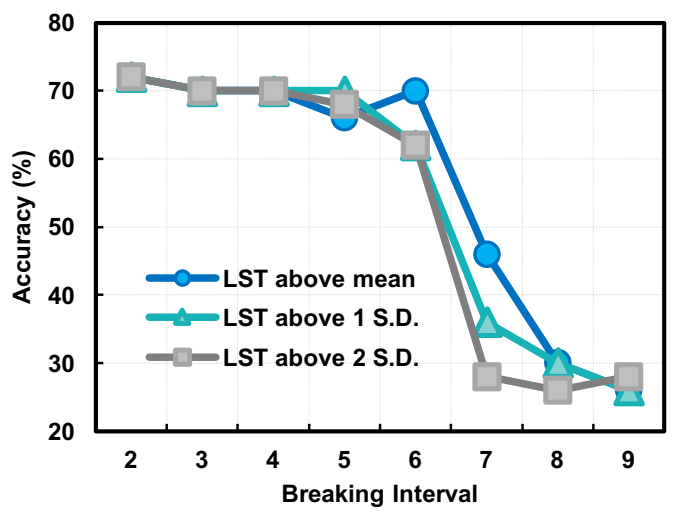

(a) Summer season

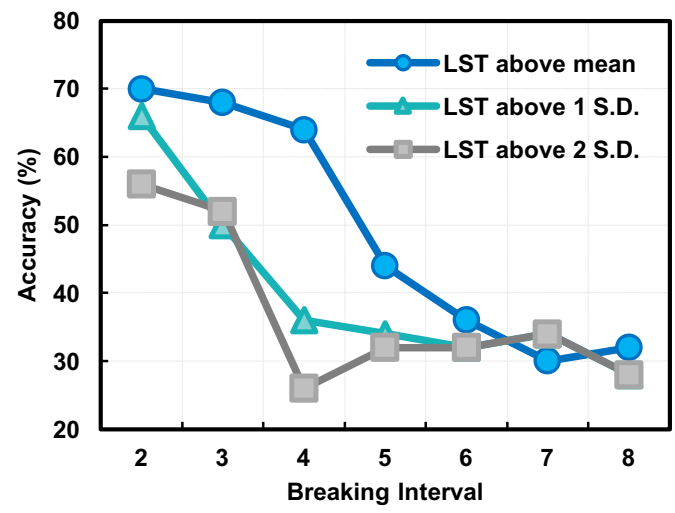

(b) Winter season

Figure 4: Overall accuracy of dumping area detection with respect to different breaking intervals.

(* Since winter 1994 was missing, a total of eight breaking intervals can be examined)

NOTE: Breaking interval is basically the number of the overlapping temperature polygons. Each year corresponded to one LST polygon. E.g. breaking interval 5 signifies that those locations within the landfill site where the LST polygons of 1-5 years intersected, were classified as landfill and rest of the areas were classified as non-landfill.

Fig. 3 shows the overall accuracy determined using the LST contours derived during the winter and summer season based on the borehole data obtained from EPA of Kuwait. Overall, the results derived from the summer season deemed to be more accurate and robust than that of the winter season when examined for accuracy according to the type of waste in boreholes. Noticeably, in case of summer, when a higher breaking interval (e.g. greater than seven) was being set, the worst accuracy can be observed within the range of $28 \%$ to $30 \%$ for winter season and $26 \%$ to $28 \%$ for 
Detection of waste dumping locations in Landfill using Multi-Temporal Landsat Thermal Images, Jasravia Gill, M. Eng, Ryerson University, 2018.

summer season respectively. This implies that the overlapping of the LST contours of all nine years

i.e. a narrow range of breaking interval, resulted in a poor accuracy assessment of the work. Although, the accuracy seemed to be consistent in the beginning i.e. (70\%) when a least breaking interval (two) was used. But gradually, the gap in the value of overall accuracy widens up, as the LST values above mean continued to be on the top with maximum accuracy, followed by LST above 1 S.D and LST above 2 S.D. respectively, as the breaking interval increases.

Finally, in the former two cases, the overall accuracy dwindled down to $26 \%$ and remained $28 \%$ for the latter. A sharp peak in the accuracy value was observed when the breaking interval was set as six. This point signifies that when the above mean LST contours of six years intersected, the accuracy of the task attained its highest value once again which further decreases at a constant rate as the breaking interval continues to increase. Therefore, it could be concluded that the breaking interval has some effect on the accuracy of the work but this effect only becomes more pronounced when the breaking interval increases above six.

Upon analysis of the winter season, the breaking interval seems to have significant effect on the accuracy of the classified results as a decrease in the accuracy could be seen as soon as the breaking interval starts to increase above three. Therefore, such a setting dramatically reduced the accuracy in the case study of winter season where the accuracy dropped from $72 \%$ (above mean) to $68 \%$ (above 1 S.D.) and finally reached to 58\% (above 2 S.D.) if all the LST contours were being used for analysis. Nevertheless, once the breaking interval was set after six, the three results did not show a significant difference, resulting in a low overall accuracy less than $40 \%$. A similar hike in the accuracy values of LST above 2 S.D. was witnessed at the breaking interval of four, resembling the 
Detection of waste dumping locations in Landfill using Multi-Temporal Landsat Thermal Images, Jasravia Gill, M. Eng, Ryerson University, 2018.

case of summer season where the accuracy of acquired results for LST above 1 S.D. followed the same trend at a breaking interval of five. Whereas, in case of LST above 1 S.D. and LST above mean, the accuracy assessment of classified results continued to steeply decrease in a constant manner and finally drops down to $28 \%$

\subsection{Analysis of the LST with respect to the waste type}

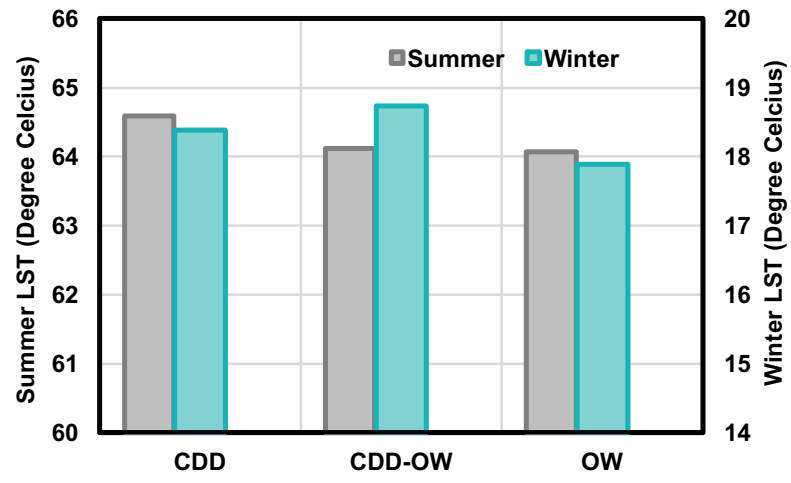

Figure 5- Analysis of LST with respect to waste type.

(Construction and Demolition Debris (CDD), Organic Waste (OW), and a mixture of Construction and Demolition Debris and Organic waste (CDD-OW).

According to the borehole data and the records of the waste type found in each borehole, three main categories of waste analysed were: Construction and Demolition Debris (CDD), Organic Waste (OW), and a mixture of Construction and Demolition Debris and Organic waste (CDD-OW). Having a close look at the average LST range of individual waste types for a period of ten years, it was observed that the construction and demolition waste continued to emit the maximum heat for prolonged period of time as compared to organic waste or a mixture of two waste types (as shown in figure 4). Perhaps, after the organic waste was completely decomposed, (which is achieved in the first six to seven years of the waste placement) the heat emission reduces considerably (Belevi and Baccini, 1989). 
Detection of waste dumping locations in Landfill using Multi-Temporal Landsat Thermal Images, Jasravia Gill, M. Eng, Ryerson University, 2018.

With the addition of OW in the CDD, the LST of the waste reduced by $0.32^{\circ} \mathrm{C}$ in winter and by $0.47^{\circ} \mathrm{C}$ in summer, respectively. However, the average LST of OW being the lowest in the three waste types varied by $0.17^{\circ} \mathrm{C}$ when compared to CDD-OW and by $0.49^{\circ} \mathrm{C}$ when compared to CDD during winter season. This variation became more pronounced in summer season where the gap widened up to $0.5^{\circ} \mathrm{C}$ in the former case and $0.52^{\circ} \mathrm{C}$ in the latter. A primary and secondary vertical axis for summer and winter were used respectively (see Fig. 4) in order compare the temperature variations in the two seasons and to depict the fact that the average temperature variations were higher in summer as compared to winter.

Overall, it could be concluded that in the three categories of waste analysed, CDD maintained to emit the highest heat flux as compared to CDD-OW and OW, during the ten-year duration. 
Detection of waste dumping locations in Landfill using Multi-Temporal Landsat Thermal Images, Jasravia Gill, M. Eng, Ryerson University, 2018.

\subsection{Potential location of dumping area}

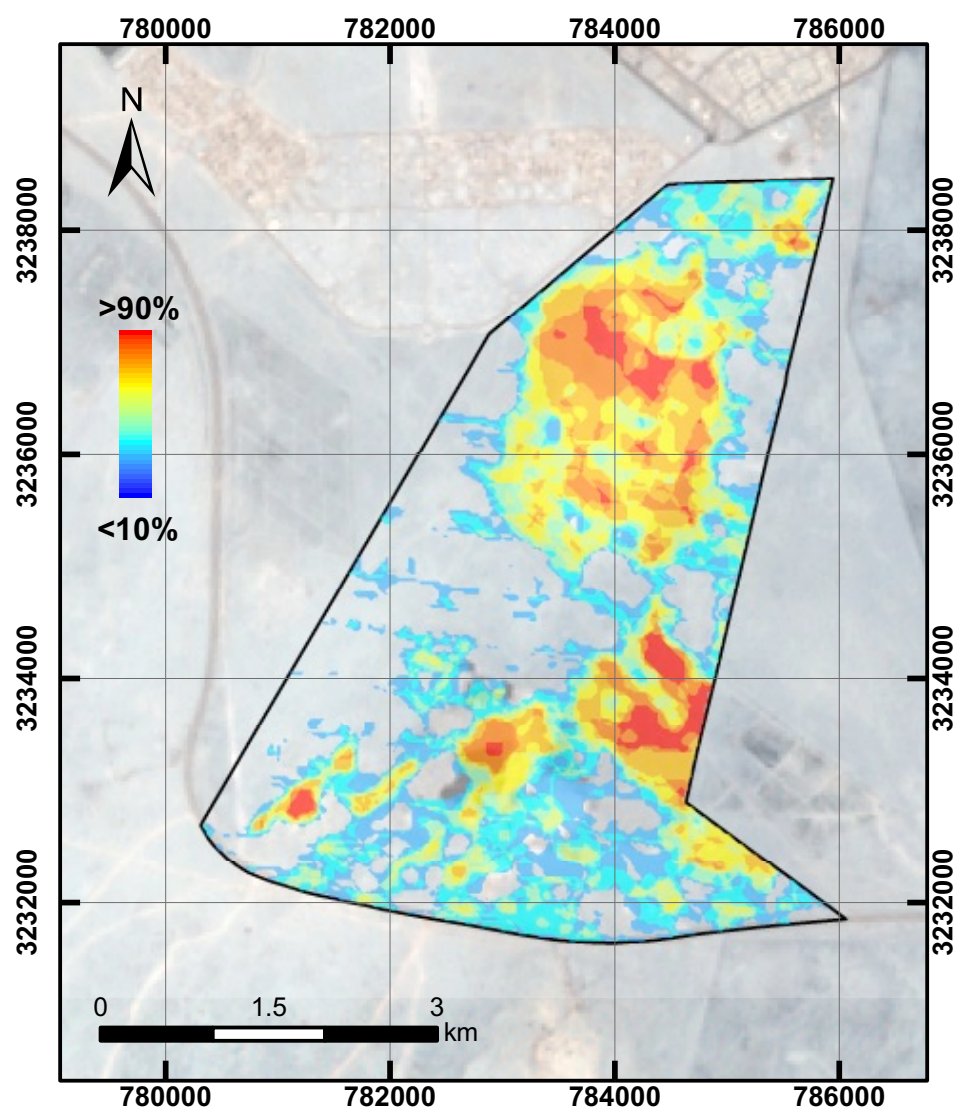

Figure 6- Probability map showing the possible dumping location within the Al-Jeleeb Shuyoukh landfill.

Although the ground truth data of Southern part of the landfill were unavailable, but it somehow reverberates to what is delineated by the aerial photo. This highlights the possibility of further future research into this area where the accuracy of the suspected dumping areas in the southern side of the landfill (as shown in the maps) could be assessed with the borehole data. Fig. 5 shows the probability map determined by the overlay analysis of the LST contour and combining the results of both summer and winter seasons. 


\section{Conclusions}

Due to the Gulf war occurred in early 1990, most the existing infrastructure's records were found missing in Kuwait. As a result, the physical dumping areas within the Al-Jeleeb Shuyoukh landfill site in Kuwait cannot be located, although both the public and the authority have a prolonged discussion of cleaning and rehabilitation for this landfill. In this study, I explored the use of multitemporal Landsat thermal images to map the LST of the landfill. Through overlay analysis of the temporal LST contours, the possible locations of the dumping areas were identified and cross checked with 50 borehole information provided by the EPA of Kuwait. The experimental work demonstrated that the maximum overall accuracy of study (based on the borehole data from EPA, Kuwait) conducted while examining the most probable locations of the waste dumping sites within the Al-Jeleeb Shuyoukh landfill site, was found to be $72 \%$ for summer season and $70 \%$ for winter.

Comparing the two seasons, it could be clearly concluded that the heat flux became more pronounced during summer and hence summer season was considered to be the better season when analysing the LST of the landfill site. While studying the accuracy, it could be verified that the breaking interval did not have much impact on the derived results of summer season, whereas the results of winter season were more sensitive to the selection of breaking interval. Apart from the accuracy assessment, the results of the average LST of three different categories of waste were examined. It was proved that the areas within the landfill site containing CDD remained to be at highest LST, followed by the mixture of OW and CDD. Also, OW remained to have minimum heat emission for a prolonged period of ten years regardless of the seasons. 
Detection of waste dumping locations in Landfill using Multi-Temporal Landsat Thermal Images, Jasravia Gill, M. Eng, Ryerson University, 2018.

\section{Appendices}
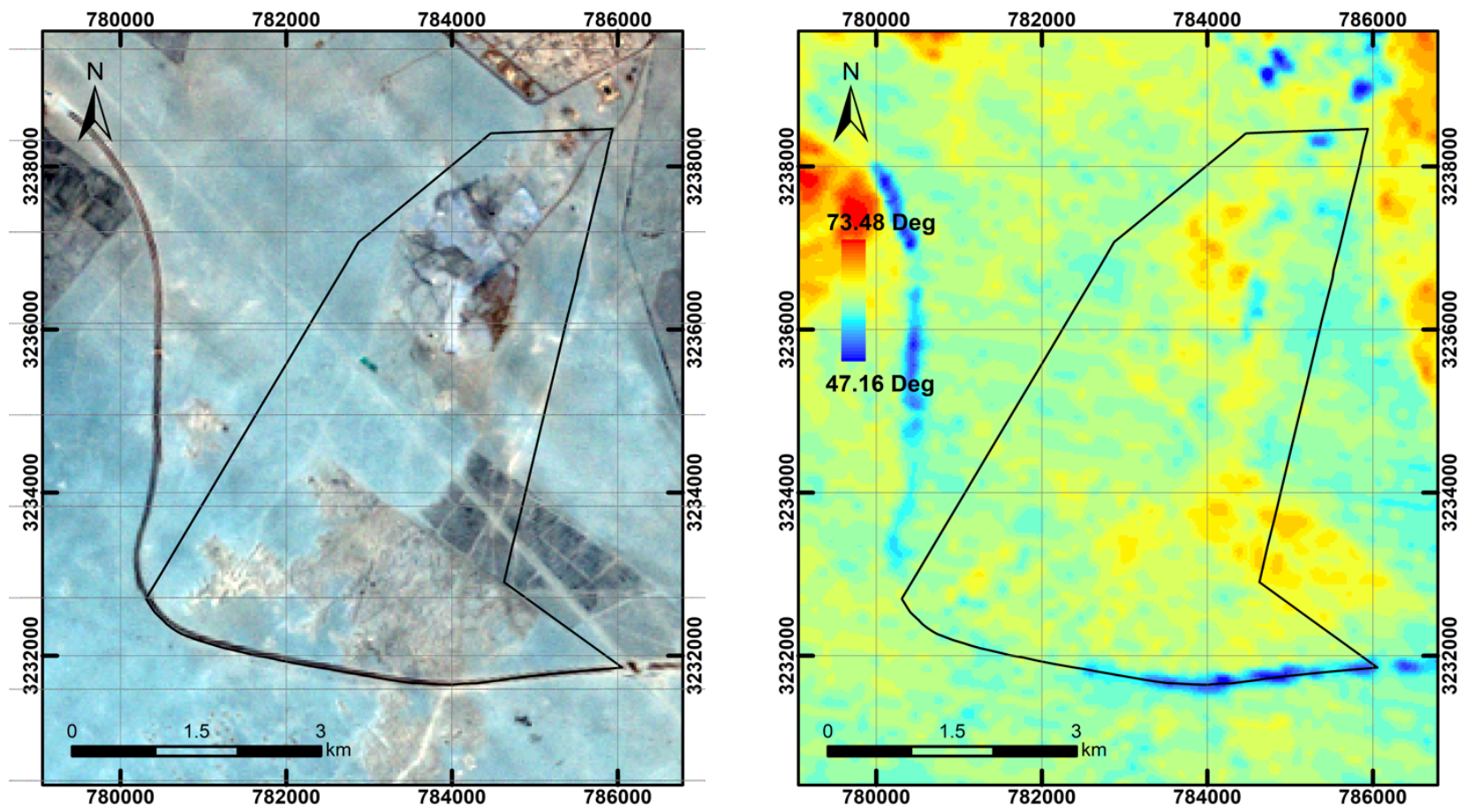

Original Landsat images acquired in Summer 1985 (left) and LST image (right)
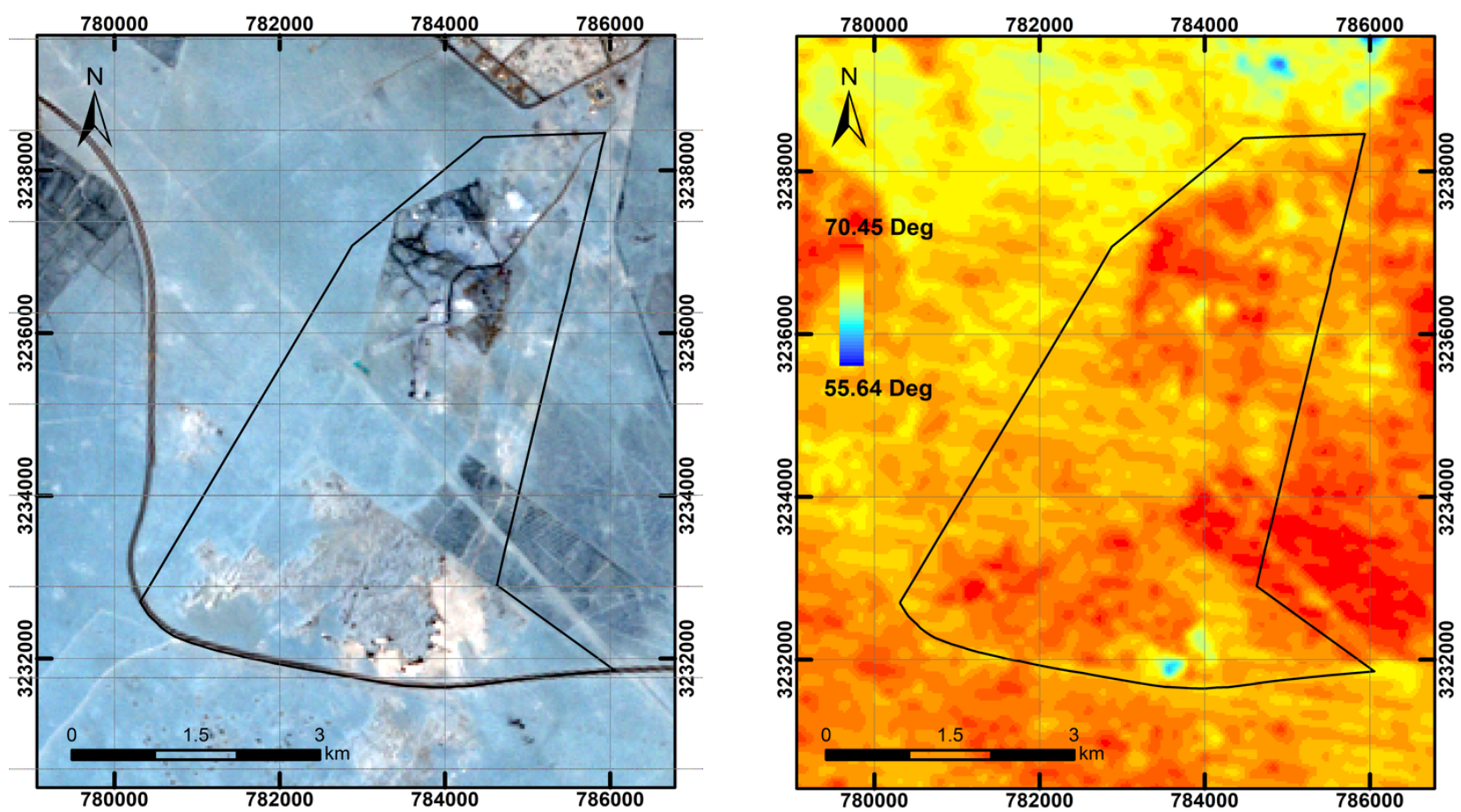
Detection of waste dumping locations in Landfill using Multi-Temporal Landsat Thermal Images, Jasravia Gill, M. Eng, Ryerson University, 2018.

Original Landsat images acquired in Summer 1988 (left) and LST image (right)
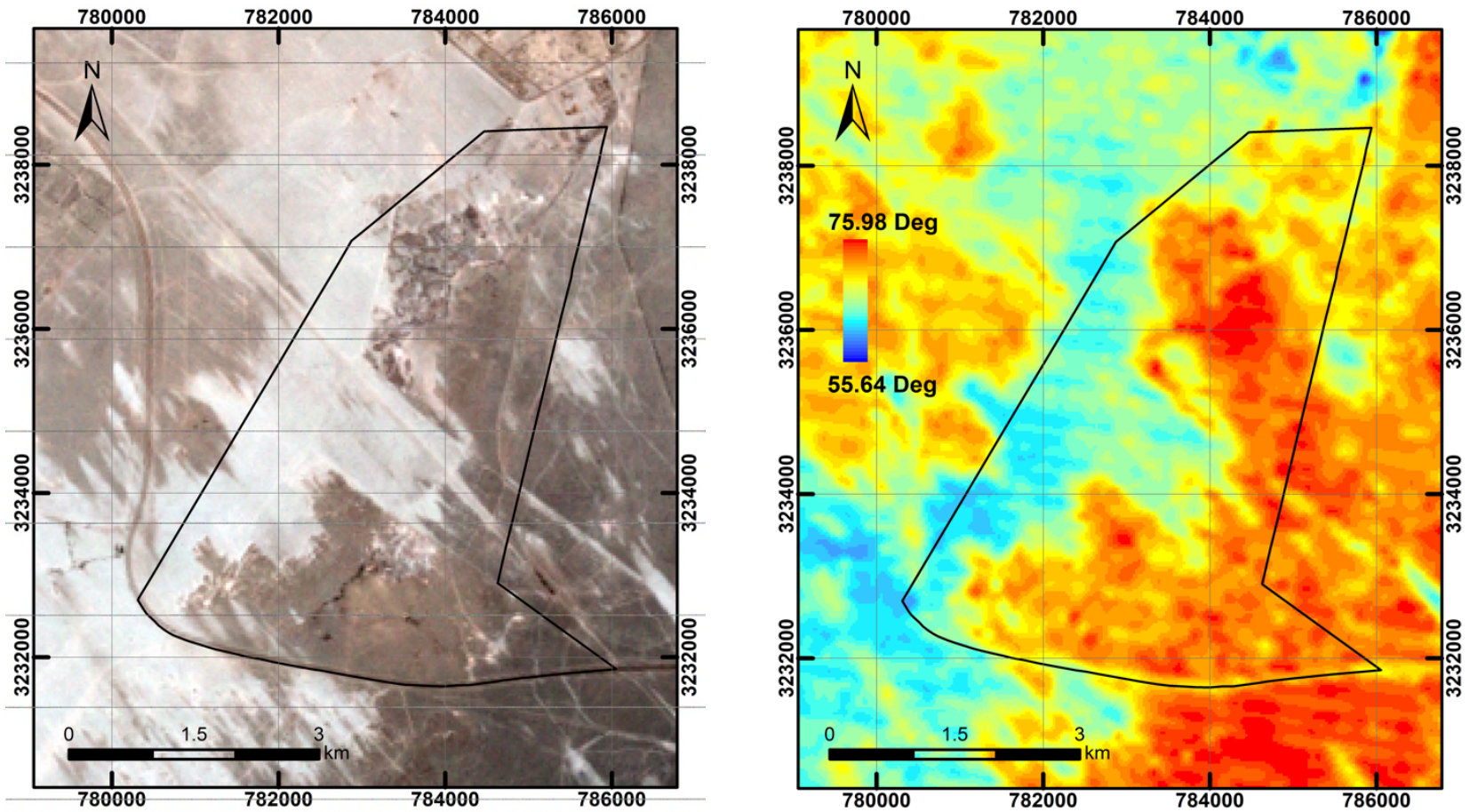

Original Landsat images acquired in Summer 1990 (left) and LST image (right)
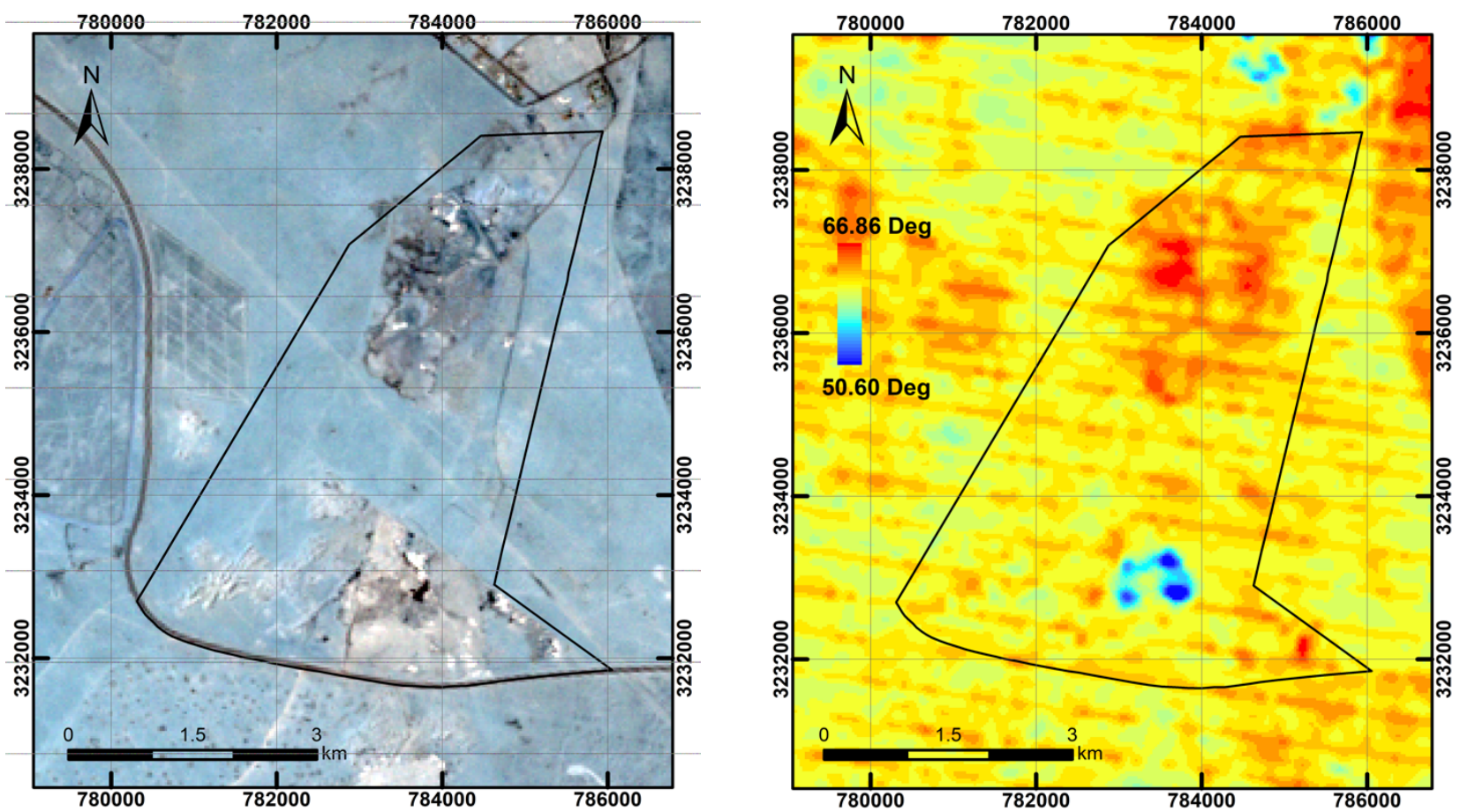

Original Landsat images acquired in Summer 1994 (left) and LST image (right) 
Detection of waste dumping locations in Landfill using Multi-Temporal Landsat Thermal Images, Jasravia Gill, M. Eng, Ryerson University, 2018.
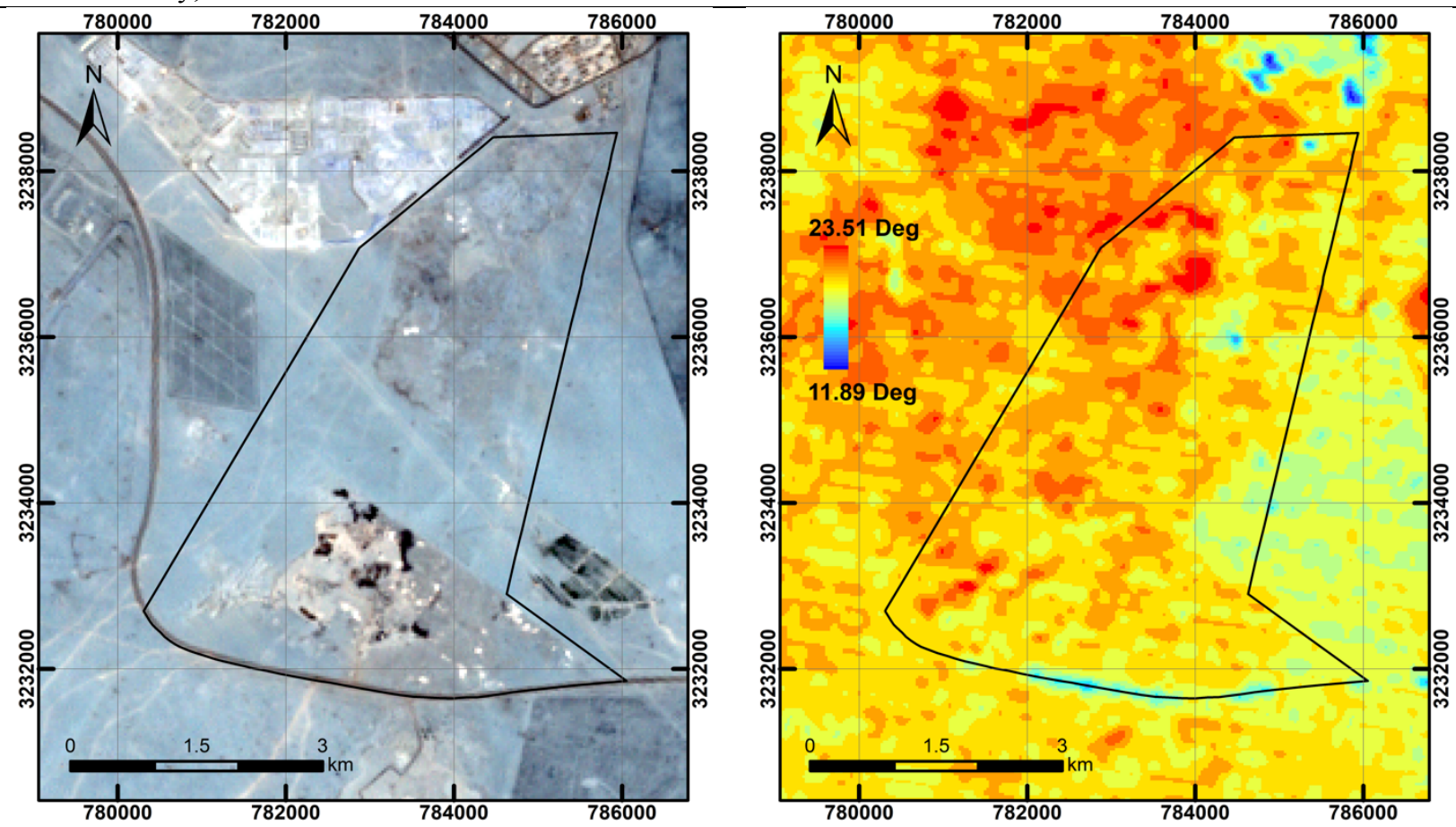

Original Landsat images acquired in Winter 1985 (left) and LST image (right)
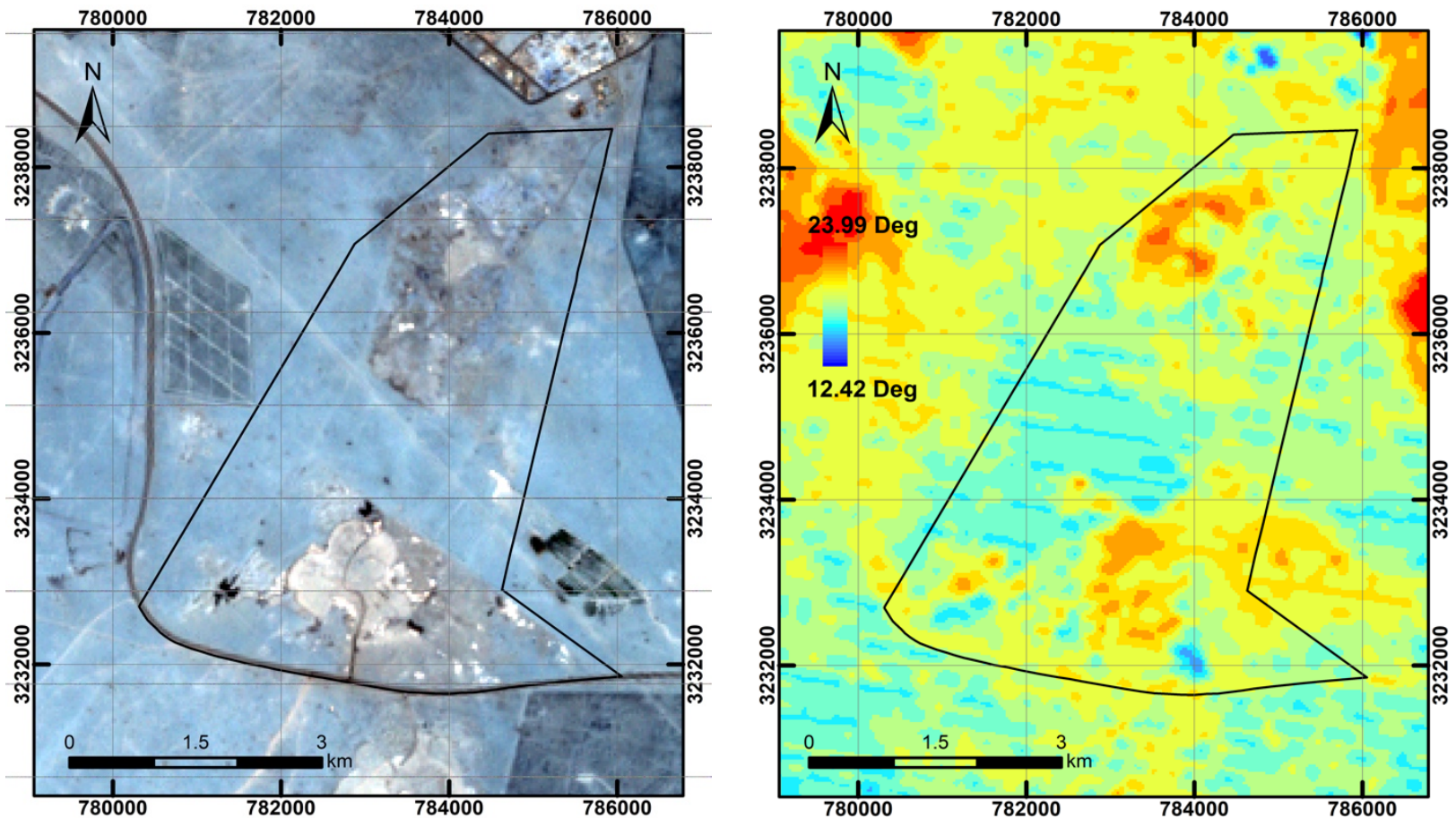
Detection of waste dumping locations in Landfill using Multi-Temporal Landsat Thermal Images, Jasravia Gill, M. Eng, Ryerson University, 2018.

Original Landsat images acquired in Winter 1988 (left) and LST image (right)
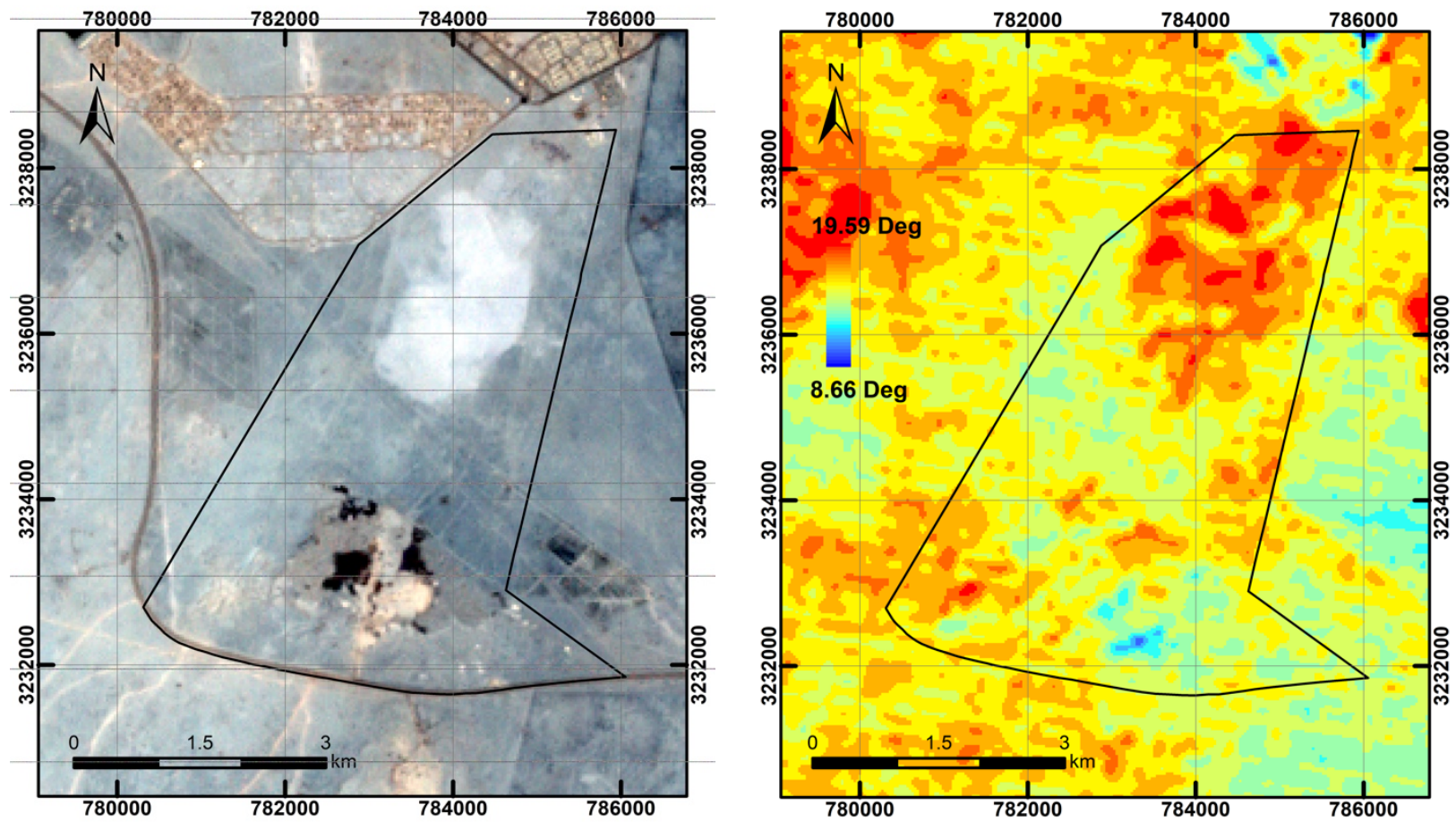

Original Landsat images acquired in Winter 1990 (left) and LST image (right)
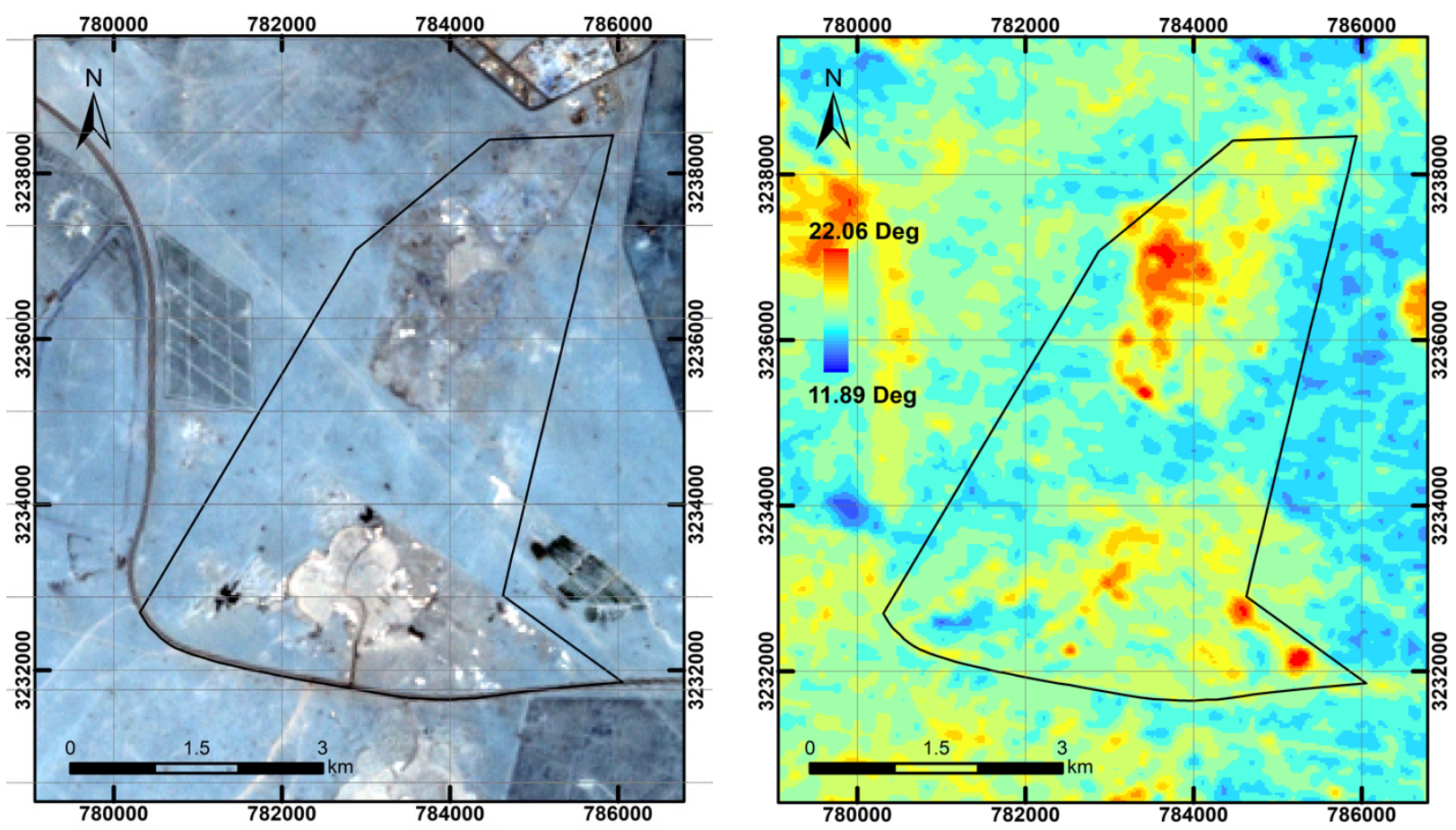
Detection of waste dumping locations in Landfill using Multi-Temporal Landsat Thermal Images, Jasravia Gill, M. Eng, Ryerson University, 2018.

Original Landsat images acquired in Winter 1993 (left) and LST image (right)

\begin{tabular}{|c|c|c|}
\hline \multirow{2}{*}{ S.no } & \multicolumn{2}{|c|}{ Acquisition Date } \\
\hline & Summer & Winter \\
\hline 1. & July 31,1985 & Jan 20,1985 \\
\hline 2. & July 2, 1986 & Jan 7, 1986 \\
\hline 3. & July 5, 1987 & Jan 10,1987 \\
\hline 4. & July 7, 1988 & Feb 6, 1988 \\
\hline 5. & July 10,1989 & Jan 15,1989 \\
\hline 6. & August 14, 1990 & Jan 18,1990 \\
\hline 7. & July 16,1991 & $\operatorname{Jan} 21,1991$ \\
\hline 8. & July 18,1992 & Jan 8, 1992 \\
\hline 9. & July 21, 1993 & Jan 26,1993 \\
\hline 10. & August 25, 1994 & $\begin{array}{l}\text { Unavailable for the required period } \\
\text { of year. }\end{array}$ \\
\hline
\end{tabular}

Table 2: Showing the acquisition dates of the downloaded Landsat Images used in the project. 


\section{References}

1. Al-Muzaini, S. M. (2009). A comparative study of the characterization of landfill leachate at the dumping sites in Kuwait. Journal of Food, Agriculture \& Environment, 7(3\&4), 679683.

2. AlAhmad, M., Dimashki, M., Nassour, A., \& Nelles, M. (2012). Characterization, concentrations and emission rates of volatile organic compounds from two major landfill sites in Kuwait. American Journal of Environmental Sciences, 8(1), 56-63.

3. Belevi, H., \& Baccini, P. (1989). Long-term behavior of municipal solid waste landfills. Waste Management \& Research, 7(1), 43-56.

4. El-Fadel, M., Findikakis, A. N., \& Leckie, J. O. (1997). Environmental impacts of solid waste landfilling. Journal of Environmental Management, 50(1), 1-25.

5. Hanson, J. L., Yeşiller, N., \& Oettle, N. K. (2009). Spatial and temporal temperature distributions in municipal solid waste landfills. Journal of Environmental Engineering, 136(8), 804-814.

6. Jensen, J. R., Hodgson, M. E., Garcia-Quijano, M., Im, J., \& Tullis, J. A. (2009). A remote sensing and GIS-assisted spatial decision support system for hazardous waste site monitoring. Photogrammetric Engineering \& Remote Sensing, 75(2), 169-177.

7. Kartam, N., Al-Mutairi, N., Al-Ghusain, I., \& Al-Humoud, J. (2004). Environmental management of construction and demolition waste in Kuwait. Waste Management, 24(10), 1049-1059. 
Detection of waste dumping locations in Landfill using Multi-Temporal Landsat Thermal Images, Jasravia Gill, M. Eng, Ryerson University, 2018.

8. Klein, R., Baumann, T., Kahapka, E., \& Niessner, R. (2001). Temperature development in a modern municipal solid waste incineration (MSWI) bottom ash landfill with regard to sustainable waste management. Journal of Hazardous Materials, 83(3), 265-280.

9. Koerner, G. R., \& Koerner, R. M. (2006). Long-term temperature monitoring of geomembranes at dry and wet landfills. Geotextiles and Geomembranes, 24(1), 72-77.

10. Kwarteng, A. Y., \& Al-Enezi, A. (2004). Assessment of Kuwait's Al-Qurain landfill using remotely sensed data. Journal of Environmental Science and Health, Part A, 39(2), 351-364.

11. Lefebvre, X., Lanini, S., \& Houi, D. (2000). The role of aerobic activity on refuse temperature rise, I. Landfill experimental study. Waste Management and Research, 18(5), $444-452$.

12. Lewis, A. W., Yuen, S. T., \& Smith, A. J. (2003). Detection of gas leakage from landfills using infrared thermography-applicability and limitations. Waste Management \& Research, 21(5), 436-447.

13. Mahmood, K., Batool, S. A., \& Chaudhry, M. N. (2016). Studying bio-thermal effects at and around MSW dumps using Satellite Remote Sensing and GIS. Waste Management, 55, 118128.

14. Mahmood, K., Batool, A., Faizi, F., Chaudhry, M. N., Ul-Haq, Z., Rana, A. D., \& Tariq, S. (2017). Bio-thermal effects of open dumps on surroundings detected by remote sensingInfluence of geographical conditions. Ecological Indicators, 82, 131-142.

15. McKendry, P. (2002). Energy production from biomass (part 2): conversion technologies. Bioresource Technology, 83(1), 47-54.

16. Nastev, M., Therrien, R., Lefebvre, R., \& Gelinas, P. (2001). Gas production and migration in landfills and geological materials. Journal of Contaminant Hydrology, 52(1), 187-211. 
Detection of waste dumping locations in Landfill using Multi-Temporal Landsat Thermal Images, Jasravia Gill, M. Eng, Ryerson University, 2018.

17. Rees, J. F. (1980). Optimisation of methane production and refuse decomposition in landfills by temperature control. Journal of Chemical Technology and Biotechnology, 30(1), 458465.

18. Richter, R., \& Schläpfer, D. (2005). Atmospheric/topographic correction for satellite imagery. DLR report DLR-IB, 565-01.

19. Rowe, R. K. (1998). Geosynthetics and the minimization of contaminant migration through barrier systems beneath solid waste. In: Proceedings of the 6th International Conference on Geosynthetics, Atlanta, USA, pp. 25-29.

20. Schrapp, K., \& Al-Mutairi, N. (2010). Associated health effects among residences near Jeleeb Al-Shuyoukh landfill. American Journal of Environmental Sciences, 6(2), 184-190.

21. Slonecker, T., Fisher, G. B., Aiello, D. P., \& Haack, B. (2010). Visible and infrared remote imaging of hazardous waste: a review. Remote Sensing, 2(11), 2474-2508.

22. Yan, W. Y., Mahendrarajah, P., Shaker, A., Faisal, K., Luong, R., \& Al-Ahmad, M. (2014). Analysis of multi-temporal landsat satellite images for monitoring land surface temperature of municipal solid waste disposal sites. Environmental Monitoring and Assessment, 186(12), 8161-8173.

23. Yeşiller, N., \& Hanson, J. L. (2003). Analysis of temperatures at a municipal solid waste landfill.

24. Yeşiller, N., Hanson, J. L., \& Liu, W. L. (2005). Heat generation in municipal solid waste landfills. Journal of Geotechnical and Geoenvironmental Engineering, 131(11), 1330-1344.

25. Yeşiller, N., Hanson, J. L., Oettle, N. K., \& Liu, W. L. (2008). Thermal analysis of cover systems in municipal solid waste landfills. Journal of Geotechnical and Geoenvironmental Engineering, 134(11), 1655-1664. 
Detection of waste dumping locations in Landfill using Multi-Temporal Landsat Thermal Images, Jasravia Gill, M. Eng, Ryerson University, 2018.

26. Faitli, J., Magyar, T., Erdélyi, A., \& Murányi, A. (2015). Characterization of thermal properties of municipal solid waste landfills. Waste Management, 36, 213-221.

27. Yoshida, H., \& Rowe, R. K. (2003, October). Consideration of landfill liner temperature. In Proceedings Sardinia.

28. Jones, H. K., \& Elgy, J. (1994). Remote sensing to assess landfill gas migration. Waste Management \& Research, 12(4), 327-337.

29. Lewis, A. W., Yuen, S. T. S., \& Smith, A. J. R. (2003, October). A case study using infrared thermography to detect landfill gas leakage. In 9th International Waste Management and Landfill Symposium S. Margherita di Pula, Cagliari, Italy (pp. 6-10).

30. Manzo, C., Mei, A., Zampetti, E., Bassani, C., Paciucci, L., \& Manetti, P. (2017). Top-down approach from satellite to terrestrial rover application for environmental monitoring of landfills. Science of The Total Environment, 584, 1333-1348. 